US Army Corps of Engineers ${ }_{\circledast}$

Engineer Research and

Development Center

Dredging Operation and Technical Support

\title{
Elevation of Underlying Basement Rock, Ogdensburg Harbor, NY
}

Heidi M. Wadman and Jesse E. McNinch

May 2021

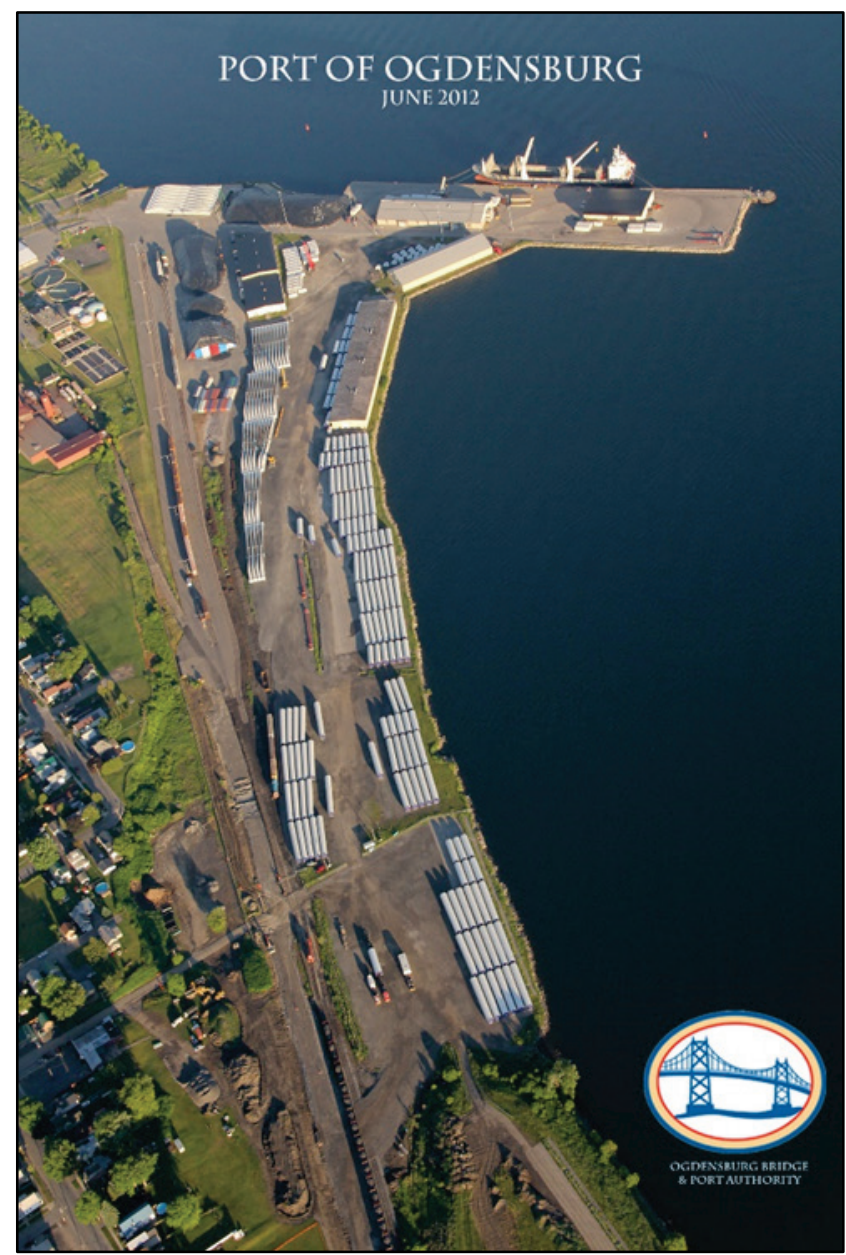

Approved for public release; distribution is unlimited. 
The US Army Engineer Research and Development Center (ERDC) solves the nation's toughest engineering and environmental challenges. ERDC develops innovative solutions in civil and military engineering, geospatial sciences, water resources, and environmental sciences for the Army, the Department of Defense, civilian agencies, and our nation's public good. Find out more at www.erdc.usace.army.mil.

To search for other technical reports published by ERDC, visit the ERDC online library at https://erdclibrary.on.worldcat.org/discovery. 


\section{Elevation of Underlying Basement Rock, Ogdensburg Harbor, NY}

Heidi M, Wadman and Jesse E. McNinch

Coastal and Hydraulics Laboratory

US Army Engineer Research and Development Center

Field Research Facility

1261 Duck Rd.

Kitty Hawk, NC 27949

Final report

Approved for public release; distribution is unlimited

Prepared for US Army Corps of Engineers, Buffalo District

Buffalo, NY 14207

Under Funding Account Code U4361444, AMSCO Code 086000, MIPR Number CCLC 35DB74 


\section{Abstract}

Over six linear miles of shallow acoustic reflection geophysical data were collected in an $800 \mathrm{ft}$ by $300 \mathrm{ft}$ survey region at Ogdensburg Harbor, Ogdensburg, NY. To better accommodate modern commercial vessels and expand the harbor's capacity, the current navigable depth of -19 ft Low Water Depth (LWD) needs to be increased to - $28 \mathrm{ft}$ LWD, and an accurate map of the nature of the riverbed material (e.g., unconsolidated sediment, partially indurated glacial till, or bedrock) is required to effectively plan for removal. A total of 28 boreholes were previously collected to map the stratigraphy, and the effort revealed significant spatial variability in unit thickness and elevation between adjacent boreholes. To accurately map this variable stratigraphy, chirp sub-bottom profiles were collected throughout the region, with an average line spacing of $13 \mathrm{ft}$. These subbottom data, validated and augmented by the borehole data, resulted in high-resolution spatial maps of stratigraphic elevation and thickness for the study area. The data will allow for more accurate assessment of the type and extent of different dredging efforts required to achieve a future uniform depth of $-28 \mathrm{ft}$ LWD for the navigable region.

DISCLAIMER: The contents of this report are not to be used for advertising, publication, or promotional purposes. Citation of trade names does not constitute an official endorsement or approval of the use of such commercial products. All product names and trademarks cited are the property of their respective owners. The findings of this report are not to be construed as an official Department of the Army position unless so designated by other authorized documents. 


\section{Contents}

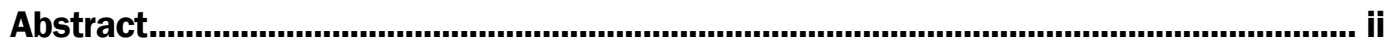

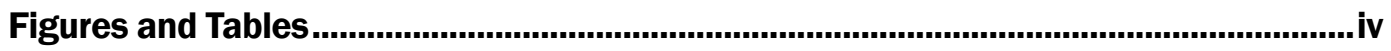

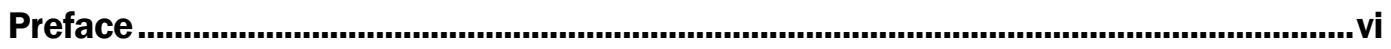

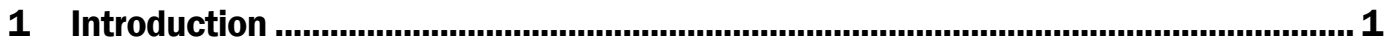

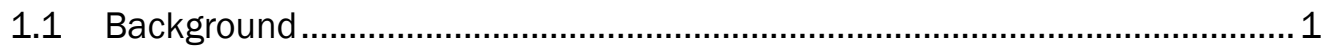

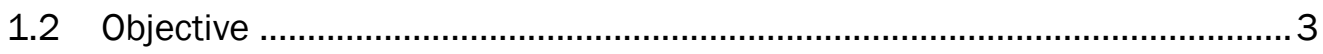

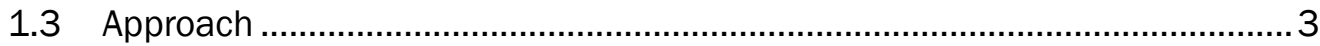

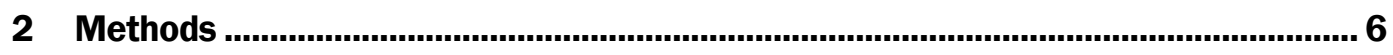

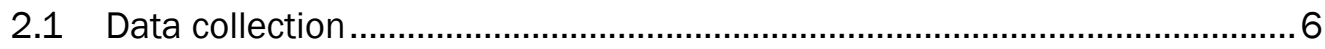

2.2 Processing and interpretation................................................................. 7

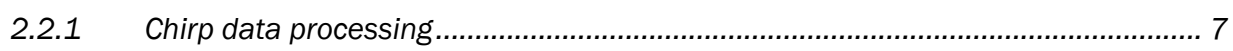

2.2.2 Integration of borehole data.......................................................................... 8

2.2.3 Identification of pertinent stratigraphic surfaces................................................. 10

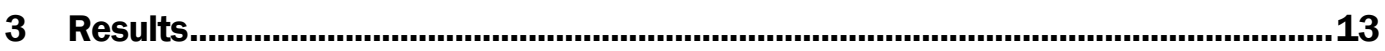

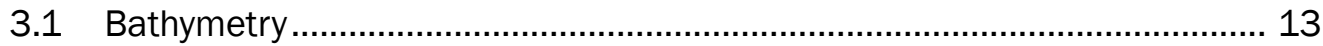

3.2 Stratigraphic elevations and thicknesses ................................................ 13

3.3 Horizontal and vertical error in the sub-bottom data ...................................15

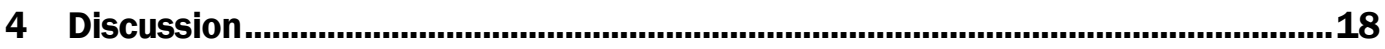

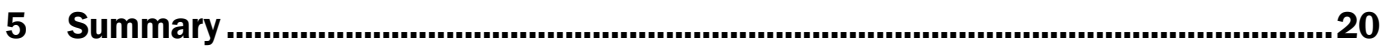

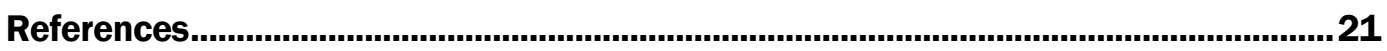

Appendix A: Chirp Sub-Bottom Files..................................................................23

Appendix B: Borehole and Chirp Comparisons .............................................................25

Report Documentation Page 


\section{Figures and Tables}

\section{Figures}

Figure 1. Location of Ogdensburg, NY, at the confluence of the St. Lawrence and Oswegatchie Rivers. The survey region, located on the western side of the port, is noted by a blue rectangle.

Figure 2. The ERDC chirp sub-bottom profiler mounted on a $16 \mathrm{ft}$ catamaran to allow mapping in shallow/narrow regions. The survey vessel is positioned to the starboard of the chirp sub-bottom profiler.

Figure 3. Examples of common geophysical survey data.

Figure 4. (A) Chirp sub-bottom survey lines superimposed on the August 15-21, 2018, bathymetry coverage map at Ogdensburg Harbor. Borehole locations from 2017 are noted by red circles. (B) Chirp towfish mounted on towing catamaran with GPS antenna centered over the transducer. Note: Image on Panel B is from a survey conducted on the St. Clair river delta in Michigan; the towfish, catamaran, and GPS configuration was identical in Ogdensburg, NY.

Figure 5. Example of a sub-bottom profile showing both Till and Sediment overlaying basement rock. Panel A provides an uninterpreted image; Panel $B$ is the same as panel A, but with interpretations. The smudging that indicates the presence of rock is noted on Panel A for clarity. Borehole D17-13 is plotted on both profiles. Sediment in the borehole is plotted in green (and corresponds with the green color used to denote R01). Till in the borehole is plotted in purple (and corresponds with the purple color used to denote R02). Note how the bases of the green Sediment and purple Till in the borehole are at the same elevations as mapped by the chirp sub-bottom profiler.

Figure 6. Example of a sub-bottom profile showing sediment overlaying Bedrock, with no Till. Panel A provides an uninterpreted image; Panel $B$ is the same as panel $A$, but with interpretations. The smudging that indicates the presence of rock is noted on Panel A for clarity. Borehole D13-02 is plotted on both profiles. Sediment in the borehole is plotted in green (and corresponds with the green color used to denote R01). Till was not observed in the borehole, and the layer was also not observed in the sub-bottom profile. Note how the base of the green Sediment and the top of the underlying Bedrock in the borehole are at the same elevations as mapped by the chirp sub-bottom profiler.

Figure 7. Bathymetric data provided by LRB at $8 \mathrm{ft}$ grid spacing.

Figure 8. Elevation of the (A): bottom of the Sediment; (B): Bottom of the Till; and (C): top of the Bedrock. All elevations in feet, rectified to the LWD of $242.4 \mathrm{ft}$, IGLD 1985

Figure 9. Thickness of stratigraphic units. (A) Sediment thickness in feet below the riverbed; (B) Till thickness in feet below the riverbed; and (C) Total thickness of Sediment and/or Till in feet above the surface of the Bedrock.

Figure 10. Ogdensburg Harbor. The yellow box represents the planned survey area. The light blue lines show the actual survey tracks.

Figure 11. Three-dimensional elevation map of the bathymetry (grey-scale), Sediment (yellow), Till (green) and Bedrock (red) at Ogdensburg Harbor.. 


\section{Tables}

Table 1. All chirp sub-bottom files collected in support of this project.................................23

Table 2. The borehole IDs and locations, the name and distance to the closest sub-bottom profile, and differences in Bedrock elevation between the boreholes

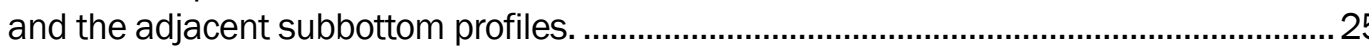




\section{Preface}

This study was conducted for the US Army Corps of Engineers (USACE) Buffalo District (LRB) and the USACE Dredging Operations and Technical Support (DOTS) Program, under the projects "DOTS Response 72, Chirp Geophysical Survey: Ogdensburg Harbor, NY," as well as the LRB projects "CCLC 35BD74 Chirp Survey Ogdensburg Harbor: Processing and Interpretation" as well as "CCLC 3F96A4 Chirp Technical Report," under Funding Account Code U4361444, AMSCO Code 086000, MIPR Number CCLC 35DB74. The technical monitors were Mr. Lex Barker (LRB) and Dr. Burton Suedel (DOTS).

The work was performed by the Coastal Observations and Analysis Branch of the Flood and Storm Protection Division, US Army Engineer Research and Development Center (ERDC), Coastal and Hydraulics Laboratory (CHL). Mr. Jay Miller and Mr. Jessie Petite, (LRB), provided significant technical assistance during data collection. At the time of publication of this report, Dr. Jeff Waters was Chief, Coastal Observations and Analysis Branch, and Dr. Cary A. Talbot was Chief, Flood and Storm Protection Division. The Deputy Director of ERDC-CHL was Mr. Keith Flowers, and the Director was Dr. Ty V. Wamsley.

The Commander of ERDC was COL Teresa A. Schlosser, and the Director was Dr. David W. Pittman. 


\section{Introduction}

In Fiscal Year 2018, the US Army Corps of Engineers, Buffalo District (LRB), with support from the US Army Engineer Research and Development Center (ERDC), Dredging Operations and Technical Support Program, conducted an acoustic, shallow reflection chirp sub-bottom survey to determine the type and elevation of material located in the Lower East Entrance Channel of Ogdensburg Harbor. The harbor requires excavation to deepen the navigation channel from $-19 \mathrm{ft}^{1,2}$ Low Water Depth (LWD) to - $28 \mathrm{ft}$ LWD, and expand deep-draft vessel storage space on the west side of the harbor. This excavation will allow larger transport vessels to safely navigate in/out of Ogdensburg Harbor.

\subsection{Background}

Ogdensburg Harbor is located in northern New York State, near the confluence of the St. Lawrence and the Oswegatchie Rivers (Figure 1). The Port of Ogdensburg has served as a distribution center since 1811 and is one of the oldest federal buildings still occupied and used by the United States. It has served as a major entry port for goods from both Canada and Europe. Over time, shoaling within the channel and along the waterfront has limited vessel access and storage space. Additionally, modern transport vessels often require a deeper draft than that available in the entry channel into the harbor, limiting the functionality of the location. Accordingly, an effort has been underway since 2013 to increase the channel draft and deepen the region adjacent to the western dock to allow for more vessel storage.

Prior to this survey, 7 combination rock/core borings were collected in December 2013, and 21 additional borings were collected in November 2017. The secondary borehole effort indicated significant spatial variation in the subsurface elevation between (1) unconsolidated sediment and underlying glacial till and (2) glacial till and underlying bedrock. Given the

\footnotetext{
${ }^{1}$ For a full list of the spelled-out forms of the units of measure used in this document, please refer to US Government Publishing Office Style Manual, 31st ed. (Washington, DC: US Government Publishing Office 2016), 248-52, https://www.govinfo.gov/content/pkg/GPO-STYLEMANUAL-2016/pdf/GPOSTYLEMANUAL-2016.pdf.

2 For a full list of the unit conversions used in this document, please refer to US Government Publishing Office Style Manual, 31st ed. (Washington, DC: US Government Publishing Office 2016), 345-7, https://www.govinfo.gov/content/pkg/GPO-STYLEMANUAL-2016/pdf/GPO-STYLEMANUAL-2016.pdf.
} 
complexity of removing the different types of material, LRB requested assistance from the ERDC Coastal and Hydraulics Laboratory in conducting a sub-bottom chirp geophysical survey of the region using its dual-spectrum chirp sub-bottom profiler to improve the resolution of the above-mentioned elevations. This profiler is mounted on a $16 \mathrm{ft}$ catamaran, allowing for operation by small vessels and/or in shallow or narrow regions (Figure 2). These data, and the previously collected borehole data, were processed by ERDC to produce contour maps showing the elevation of the contacts described above and isopach maps of the unconsolidated sediment and glacial till. These data will be used to refine the dredging and excavation plan for the harbor deepening effort.

Figure 1. Location of Ogdensburg, NY, at the confluence of the St. Lawrence and Oswegatchie Rivers. The survey region, located on the western side of the port, is noted by a blue rectangle.

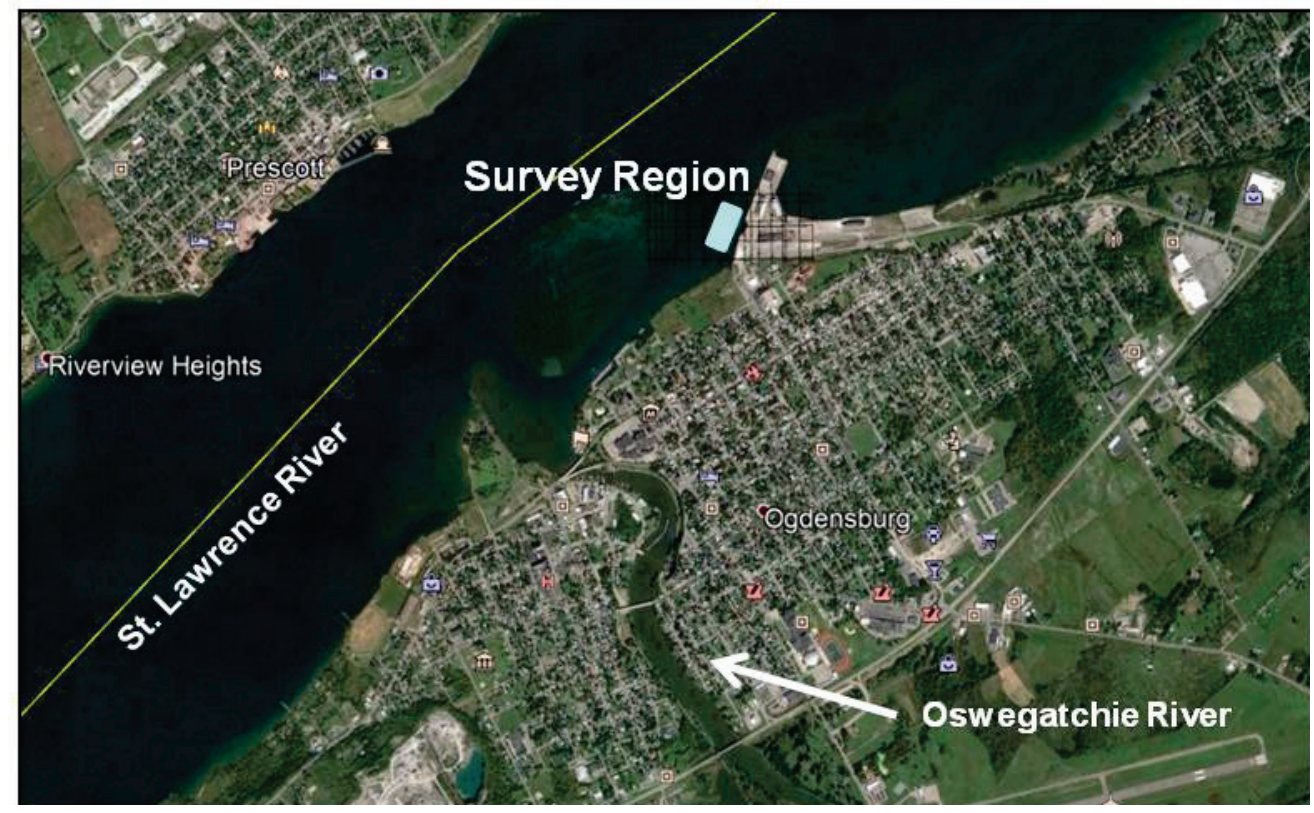


Figure 2. The ERDC chirp sub-bottom profiler mounted on a $16 \mathrm{ft}$ catamaran to allow mapping in shallow/narrow regions. The survey vessel is positioned to the starboard of the chirp sub-bottom profiler.

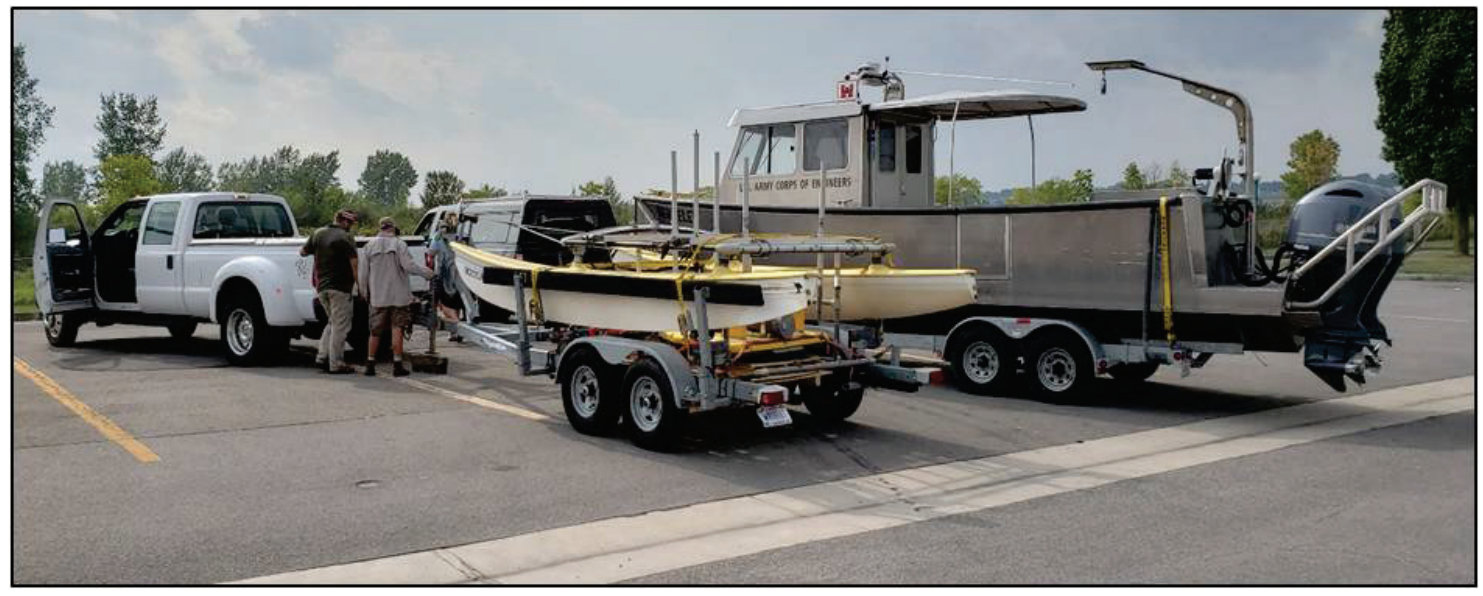

\subsection{Objective}

To refine the types of dredging and volumes of material to be removed to deepen the usable region of Ogdensburg Harbor, NY, a shallow acoustic reflection surface (sub-bottom profiling) was conducted to map the elevations and thicknesses of significant stratigraphic units (Sediment, Till, and Bedrock). The study region encompassed the entrance channel as well as a planned extension of the current vessel storage area along the western harbor.

\subsection{Approach}

All acoustic geophysical mapping methodologies share the same basic relationship: the geophysical equipment, referred to as a towfish, is towed from a survey vessel, and a sound source is generated from a transducer in the towfish towards the sediment-water interface (referred hereafter as the "riverbed"). The density change at the riverbed reflects the sound back to the surface where it is detected by receivers either embedded in the towfish or towed behind the towfish or vessel (Figure 3). Since the frequency of the acoustic pulse is known, the two-way travel time provides a measure of the distance (or water depth) between the towfish and the riverbed, as well as the distance (or depth) of the subsequent subsurface geologic layers. Further, the strength of the returned signal (referred to as the signal's amplitude) is a measure of the acoustic impedance of the geologic unit, which in turn is directly related to the density of the sediment. Thus, the amplitude of the acoustic return can be used to delineate the geologic nature of the sediment mapped by the towfish. 
Specifically, softer, less dense sediment (e.g., silt or clay) reflects less energy and thus has a lower amplitude return than more dense sediment (e.g., sand or gravel).

Figure 3. Examples of common geophysical survey data.

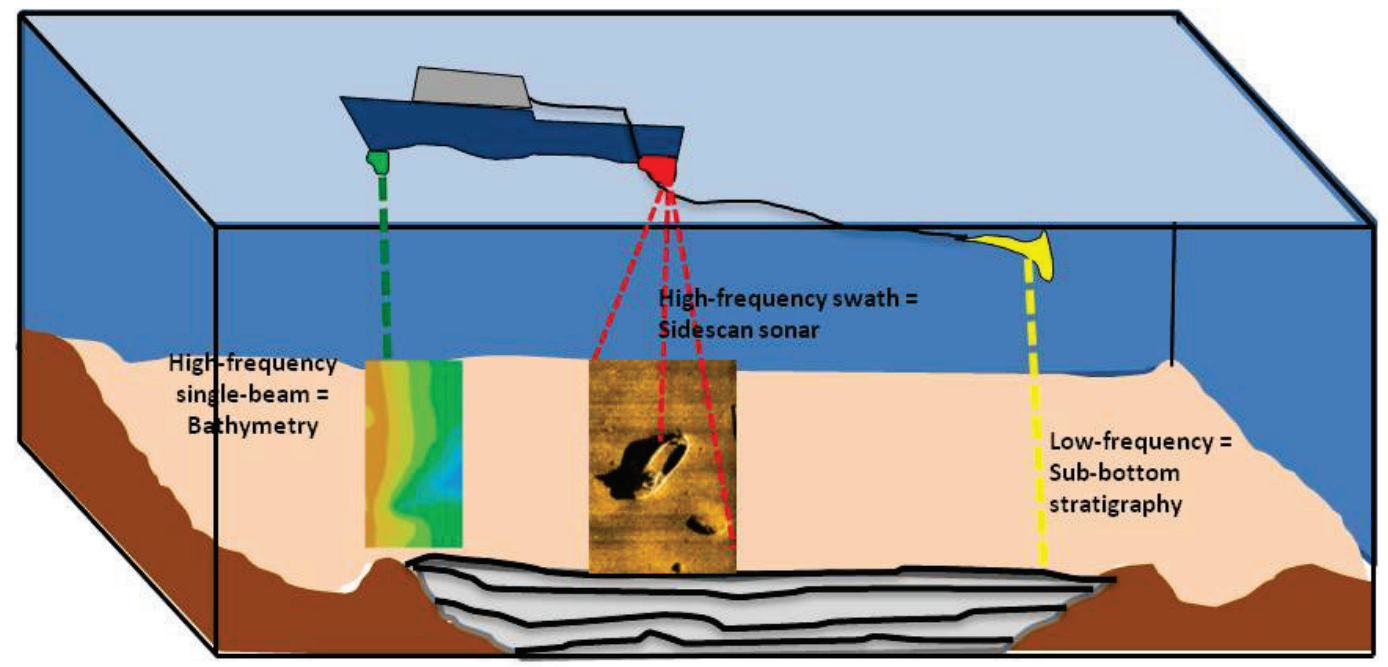

To map the thickness of surface sediments and the associated stratigraphy below the riverbed, lower acoustic frequencies must be utilized than those used by bathymetric or sidescan sonar systems. Although multiple strategies exist for generating these pulses, frequency-modulated, acoustic chirp reflection systems are considered the industry standard for acquiring stratigraphic data in shallow, aqueous environments (e.g., Schock and LeBlanc 1990; LeBlanc et al. 1992; Roberts and Supan 2000; Schock 2004; Lee et al. 2009). Chirp systems produce a frequency-modulated range of acoustic frequencies with each acoustic pulse (similar in audible sound to a bird chirp) and provide a range of lower frequencies than those used for bathymetry or sidescan sonar applications. These lower frequencies are able to penetrate the sediment-water interface and thus are transmitted into the underlying sediments. Rather than only mapping a single density change (referred to as a "reflection") from a single frequency acoustic pulse at the water/sediment interface, the different frequencies in a chirp pulse are reflected off of changes in density in the subsurface sediment. Since each chirp acoustic pulse is comprised of a range of frequencies, each of the different acoustic frequencies on the same chirp pulse are reflected at different amplitudes and time from different density changes and depths, allowing a detailed map of subsurface stratigraphy to be created. Acoustic chirp reflection systems have been utilized to map the shallow stratigraphy of a wide range of 
aqueous environments (e.g., Schock and LeBlanc 1990; Schock 2004; Roberts and Supan 2000), including rivers and estuaries (e.g., Carbotte et al. 2004; Nitsche et al. 2004; Nitsche et al. 2007; Plets et al. 2009), lacustrine (e.g., Schwamborn et al. 2002; Cukur et al. 2013; Cukur et al. 2015), and shallow coastal environments (e.g., LeBlanc et al. 1992; Schock 2004; Lee et al. 2009).

A limitation inherent in shallow acoustic chirp sub-bottom systems is that the signal is usually completely reflected back from solid rock with no penetration (e.g., Morang et al. 1997; Gutowski et al. 2008; Demarco et al. 2017; Wadman and McNinch 2020), so these systems provide little to no data about the lithology of the rock material. With respect to indurated sediment, larger towfish, such as the EdgeTech CSS-2000, have sufficiently large enough piezoceramic plates and a flat transmitted energy profile (providing equal power across all acoustic frequencies of each single acoustic chirp), which allows limited penetration into partially lithified material to potentially include glacial till (e.g., Morang et al. 1997; Gutowski et al. 2008; Felix et al. 2013; Wadman and McNinch 2020). 


\section{Methods}

To identify the nature/depth of rock/till/sediment contacts, a chirp subbottom survey was conducted on 27-28 August 2018 by LRB and ERDC personnel.

\subsection{Data collection}

A total of 52 survey lines, covering six linear miles of chirp sub-bottom profiles (Figure 4a), were collected over the $800 \mathrm{ft}$ by $300 \mathrm{ft}$ survey region using an EdgeTech CSS-2000 integrated sub-bottom profiler and sidescan sonar. The chirp towfish was mounted on a $16 \mathrm{ft}$ towed catamaran to allow safe manipulation of the $\sim 800 \mathrm{lb}$ towfish by the small survey vessel (Figure 4b). The Global Positioning System (GPS) antenna was mounted on the chirp catamaran directly above the center of the towfish. Data were collected in NY State Plane, East Zone, US feet, coordinates using differential GPS. The accuracy of this positioning system is explored further in Section 3.3. The vertical datum for the chirp sub-bottom data during collection was the water/sediment interface (e.g., the riverbed) and was rectified later to the LWD of $242.4 \mathrm{ft}$ International Great Lakes Datum (IGLD) 1985 using a bathymetry survey collected by LRB during 15-21 August 2018 (see Section 3 for details).

A line spacing of $50 \mathrm{ft}$ in the shore parallel direction was initially planned for this effort. Due to issues with Hypack software, the GPS string was imported directly into the chirp acquisition software: Chesapeake Technology SonarWiz V7.01.006. To accommodate the inability of Hypack to run in Survey mode, the original planned survey extents for the region were identified in Google Earth and imported into SonarWiz as a .kmz file. Survey lines were then re-generated using SonarWiz, and a steering indicator was extended to the vessel operator. Survey lines were followed as best as possible, given the steering limitations of vessel speed (no more than $2 \mathrm{kn}$ to allow sufficient acoustic listening time) and water conditions. Sonar frequency (pulse), record length, trigger length, and power varied between different survey lines, and specific details for each survey line are provided in Appendix A. Ultimately, water conditions (small craft advisory on both survey days) precluded the collection of data in a regular-spaced grid. Accordingly, the survey region was expanded outside of the initial region in question to allow for more turning room for the survey vessel under the harsh weather conditions. In addition, additional survey lines 
(e.g., closer than 50 horizontal feet apart) were added to the plan to maximize coverage of the study area.

Figure 4. (A) Chirp sub-bottom survey lines superimposed on the August 15-21, 2018, bathymetry coverage map at Ogdensburg Harbor. Borehole locations from 2017 are noted by red circles. (B) Chirp towfish mounted on towing catamaran with GPS antenna centered over the transducer. Note: Image on Panel B is from a survey conducted on the St. Clair river delta in Michigan; the towfish, catamaran, and GPS configuration were identical in Ogdensburg, NY.

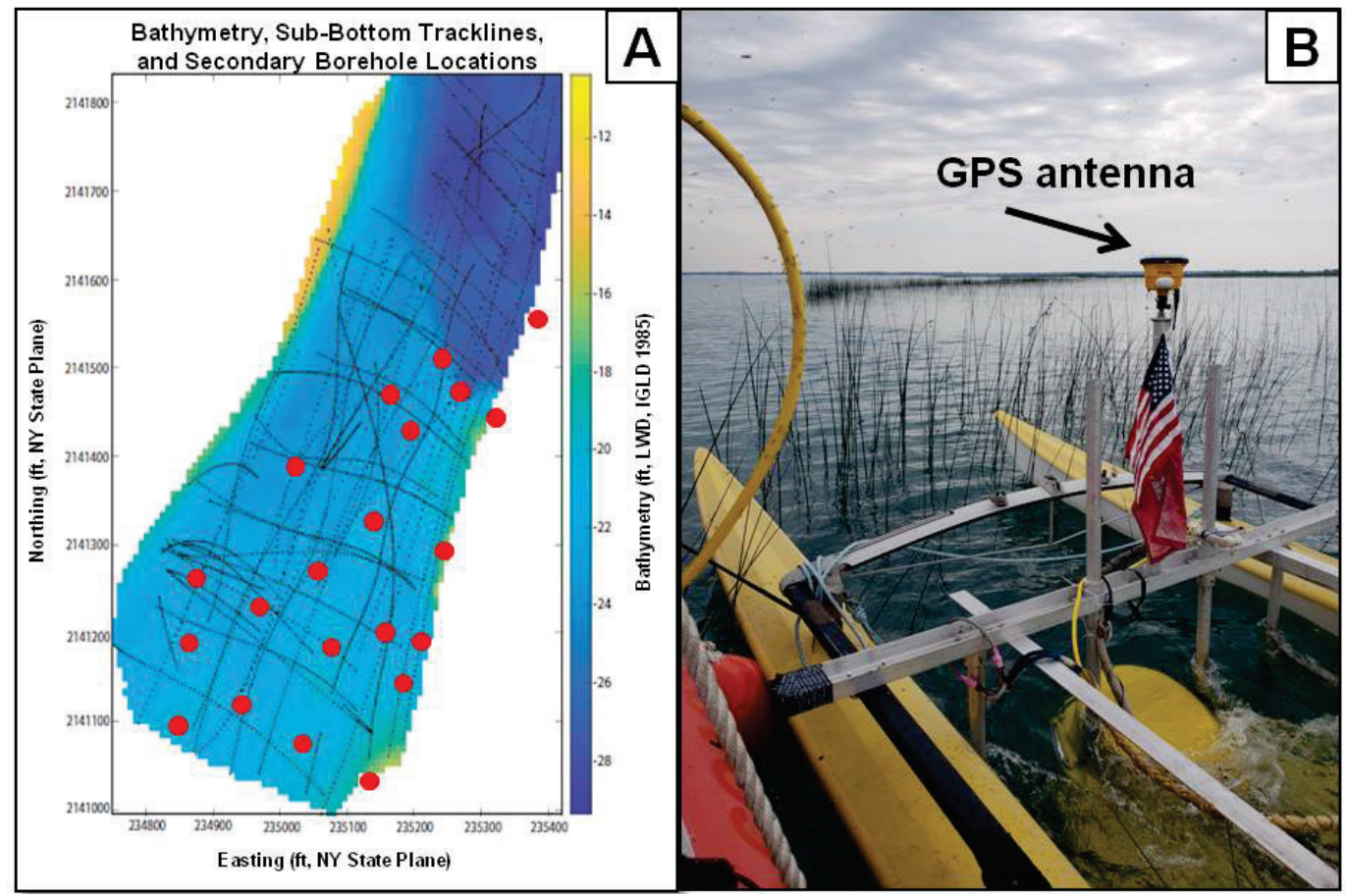

\subsection{Processing and interpretation}

Chirp sub-bottom data were imported into Chesapeake Technology SonarWiz 6 V6.05.0020 for processing and interpretation. Preliminary data processing included identification of Sediment, Till, and Bedrock units in the chirp record, and digitization of relevant reflection surfaces. All data were initially gridded at a resolution of $10 \mathrm{ft}$ to allow a first-order assessment of quality assurance/quality control as well as preliminary borehole comparisons. The final gridding was completed using Matlab, including rectification of the digitized surfaces to the vertical datum.

\subsubsection{Chirp data processing}

During acquisition, SonarWiz captures the entire potential length of the acoustic record, which generally includes depths significantly deeper than the actual data recorded. Accordingly, the lower 50\% $-60 \%$ of each data file 
was trimmed to maximize the data returned by the towfish (line-specific settings are noted in Appendix A). Of the 52 total lines collected, 48 were found to have useable data. Four data files recorded extensive acoustic noise that obscured any useable data and were not used in the data analysis effort. The SonarWiz automated bottom tracking mode was used to identify the sediment/water interface for each useable line, and each line was visually checked and edited as necessary to ensure proper riverbed identification. On lines that imaged extensive water column noise (usually heavy bubbles due to choppy waves) or schools of fish, the SonarWiz bottom tracker could not confidently identify the riverbed. The sediment/water interface was identified and digitized on those lines by hand. Gain was not applied during post-processing; color and contrast were adjusted for individual lines during interpretation but were not permanently applied. A heave filter for the sub-bottom towfish was not available, and thus digitization of all pertinent reflection surfaces was applied through the heave and completed by one individual to eliminate the errors that often result when more than one person participates in data interpretation.

For this effort, three reflection surfaces were digitized: (1) the riverbed surface (referred to as Seafloor by SonarWiz); (2) the base of Sedimentary material (also the top of the Till layer; labeled as Ro2); and (3) the base of the Till layer (also the top of the Bedrock; labeled as R01). Details for how each surface was identified are provided in Section 2.2.3, and which reflection surfaces were identified on a given sub-bottom line are listed in Appendix A. The difference in elevation between the riverbed and the above-described reflection surfaces was calculated by SonarWiz and exported as .csv files for further analysis using Golden Software Surfer, V15.1.285, to check for issues in digitization. All line-specific settings are provided in the Appendix A.

\subsubsection{Integration of borehole data}

Previously collected borehole logs were provided to ERDC by LRB for comparison to the chirp data. Details regarding borehole collection and individual borehole logs can be provided by LRB on request. Each borehole log indicated the elevation and thickness of various sediment layers, the underlying till, and the bedrock. Although the borehole logs do provide detail on different unconsolidated sediment layers (e.g., fill vs. sand vs. clay), all unconsolidated sediment was grouped into a single "Sediment" group for this effort, since (1) the focus of this effort is to map the thickness of all unconsolidated Sediment above the surface of the till 
(as well as the till thickness itself), and the actual nature of the sediment itself is not relevant for this effort; and (2) to image through multiple feet of sediment and indurated till, lower frequency acoustic pulses were required. These pulses allow for greater penetration and resolution of the contact between unconsolidated sediment and dense till, plus penetration and resolution between indurated till and solid rock, but at a loss of resolution of the subtle density differences within the overlying sediment (e.g., sand vs. clay). Accordingly, the thickness of all unconsolidated sediment, regardless of grainsize, was grouped into a single "Sediment" unit for comparison purposes. The stratigraphic unit comprised of partially indurated till is referred to as "Till," and the underlying basement rock is referred to as "Bedrock."

Once provided, the location of each borehole was plotted as a feature in SonarWiz, and its proximity to the sub-bottom profiles was calculated; those distances are provided in Appendix B. Due to the significant variability in the elevation of the pertinent reflection surfaces, and the variability previously observed in the sediment/till/bedrock elevations between adjacent boreholes, only boreholes located within five linear feet of a sub-bottom profile were used for exact comparison of the reflection surfaces vs. the observed stratigraphy. Of the 28 boreholes collected, 6 were located within one linear foot of a sub-bottom profile, and an additional 9 were located within five linear feet of a sub-bottom profile. Overall, the average difference between the elevations of pertinent units in the boreholes was within $0.22 \mathrm{ft}$ (standard deviation of $1.40 \mathrm{ft}$ ) of the elevation of the same unit on the adjacent sub-bottom profile, and detailed differences are provided in Section 3.3 and Appendix B. The impact of these differences on overall vertical error is further explained in Section 3.3. The remaining boreholes were used to elucidate general stratigraphic patterns between adjacent sub-bottom profiles, but the elevations of contacts were not directly used to validate the sub-bottom data. Details of which boreholes were used, and which sub-bottom lines they were closest to, are provided in Appendix B.

Once digitized, the riverbed (seafloor), the base of the Sediment and/or top of the Till (Ro2), and the base of the till/top of the Bedrock (Ro1) were all exported as .csv files and imported into Golden Software Surfer v.14.3.691. The data were gridded in Surfer using Kriging with a search radius of $5 \mathrm{ft}$ to identify any obvious digitization errors. Kriging is a common geostatistical gridding method that allows for accurate data 
interpolation over regions that include irregularly spaced data points. Once all digitization errors were rectified and corrected in SonarWiz, the corrected data were converted into ASCII for importation into Matlab v2018_9.4 for calculations of layer elevations and thicknesses.

\subsubsection{Identification of pertinent stratigraphic surfaces}

The purpose of this study was to identify the highly variable elevations of the base of unconsolidated sediment, the base of partially indurated glacial till, and the top of the bedrock. Many boreholes indicated that the glacial till and unconsolidated sediment layers were not present throughout the site; instead, in some locations unconsolidated sediment was observed to directly overlay bedrock with no till, or no unconsolidated sediment was observed overlying till. The above variability was also observed in the chirp subbottom profiles. As briefly described in Section 2.2.1, differences in density below the riverbed reflect acoustic energy back to the towfish, generating a dark line on a seismic profile, which is initially identified as a reflection surface and numbered (e.g., Ro1 and R02). Reflection surfaces associated with less dense material (e.g., sediment layers) have lower amplitudes than denser layers (e.g., indurated till), and, in addition, often look lighter in color and more discontinuous on a given sub-bottom profile. Also, much of the acoustic pulse penetrates into unconsolidated sediment and can be reflected off of lower density changes, resulting in multiple reflection surfaces. In contrast, the top of an indurated layer is harder (denser) than unconsolidated sediment, resulting in an overall darker appearance as a function of the higher amplitude of the returning acoustic signal.

Although most of the acoustic pulse is reflected back to the towfish from a harder, indurated stratigraphic contact, the lower frequency range of a highpowered acoustic pulse can penetrate into the indurated layer and be reflected back to the towfish if it encounters a lower, strong density change, specifically a contact between overlying indurated material and underlying bedrock. With very rare exceptions, all acoustic energy is reflected back to the towfish upon encountering rock, leaving a smudged appearance below the rock contact, and no lower reflection surfaces. Examples of all of these contacts are shown in Figure 5. In addition to the reflection surfaces noted previously, bottom multiples were observed in all of the sub-bottom profiles. These artifacts occur when, for example, the sound penetrates into the riverbed, is reflected back to the towfish, and then is reflected back down into the riverbed again, only to be reflected back to the towfish a second time. This produces a mirror image of the original reflection 
surface(s) at exactly $2 x$ the depth of the first (correct) return of the original reflection surface(s). These multiples are noted in Figures 5 and 6.

After the riverbed was digitized, the first stratigraphic surface digitized was that of the surface of the underlying Bedrock and is referred to in this report as Ro1. The acoustic record below Ro1 is smudged and dark, with no reflection surfaces observed below it. The distance between the riverbed and the surface of the basement rock was compared between the chirp subbottom profiles and nearby borehole logs, and both data sets indicated the same depth to rock at the same locations, within the vertical error of the sub-bottom data. Vertical error is explored more fully in Section 3.3.

Visible in the sub-bottom profiles between the riverbed and the underlying Bedrock is either unconsolidated Sediment and Till, just unconsolidated Sediment, or just Till. This is consistent with similar observations from boreholes, many of which indicated that there is no Sediment above the Till or that there is no Till between the unconsolidated surface Sediment and underlying Bedrock. The base of the unconsolidated Sediment (and thus the surface of the Till where present) was digitized as Ro2. Figure 5 shows an example of a typical sub-bottom profile with two lower reflection surfaces digitized: Ro1: the top of the Bedrock, and Ro2: the base of the Sediment and top of the Till. An example of a region without only Sediment overlying the Bedrock (and thus no Till in either the borehole or the sub-bottom data) is shown in Figure 6.

Figure 5. Example of a sub-bottom profile showing both Till and Sediment overlaying basement rock. Panel A provides an uninterpreted image; Panel $B$ is the same as panel A, but with interpretations. The smudging that indicates the presence of rock is noted on Panel A for clarity. Borehole D17-13 is plotted on both profiles. Sediment in the borehole is plotted in green (and corresponds with the green color used to denote R01). Till in the borehole is plotted in purple (and corresponds with the purple color used to denote R02). Note how the bases of the green Sediment and purple Till in the borehole are at the same elevations as mapped by the chirp sub-bottom profiler.
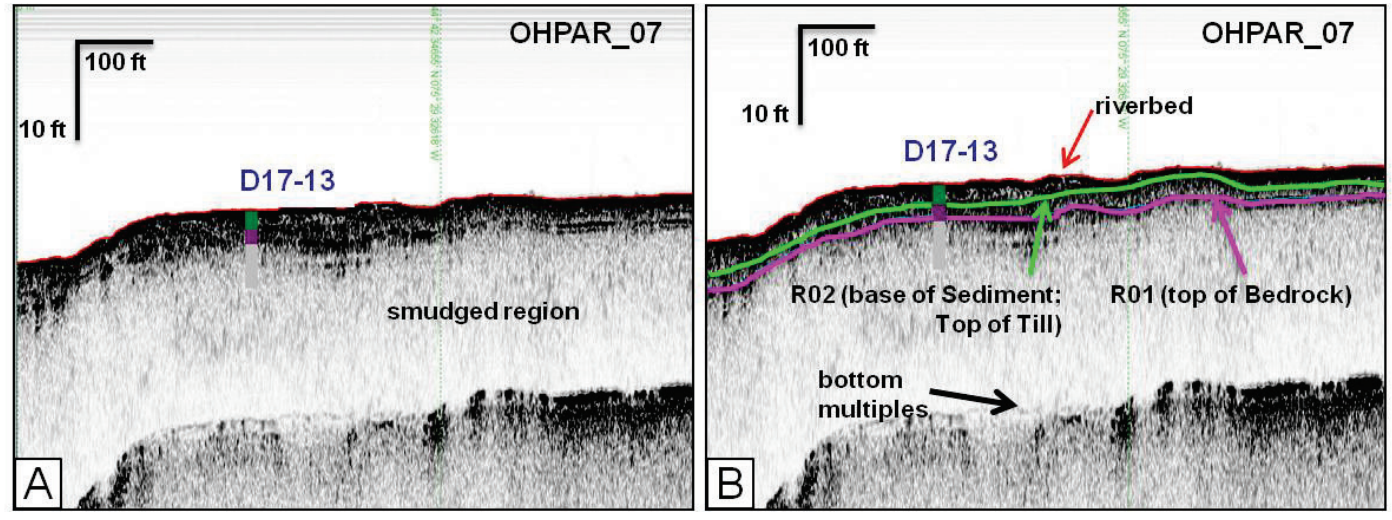
Figure 6. Example of a sub-bottom profile showing sediment overlaying Bedrock, with no Till. Panel A provides an uninterpreted image; Panel B is the same as panel A, but with interpretations. The smudging that indicates the presence of rock is noted on

Panel A for clarity. Borehole D13-02 is plotted on both profiles. Sediment in the borehole is plotted in green (and corresponds with the green color used to denote R01). Till was not observed in the borehole, and the layer was also not observed in the sub-bottom profile. Note how the base of the green Sediment and the top of the underlying Bedrock in the borehole are at the same elevations as mapped by the chirp sub-bottom profiler.

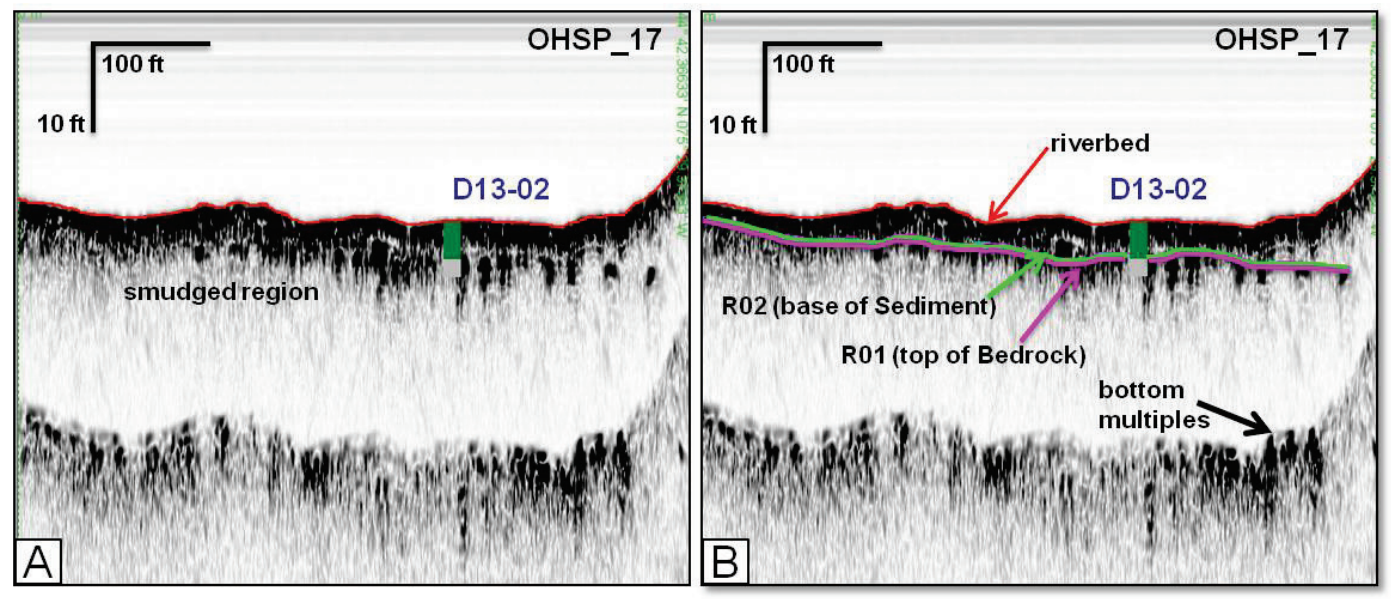

Where Till was observed between the sediment and the underlying rock, there is a vertical distance between Ro1 and Ro2, as shown in Figure 5 . Where there is no Till, Ro1 and Ro2 were digitized at the same elevation, as shown on Figure 6, and the depth below the towfish of Ro2 was used to delineate the thickness of the Sediment where present (e.g., it represents the base of the Sediment), or the thickness of the Till (e.g., it represents the base of the Till) when there is no Sediment. The elevations of Ro1 and Ro2 below the towfish were then subtracted from the elevation of the riverbed below the towfish and exported from SonarWiz as positive values (depth below the riverbed). These data were then used to generate rectified Sediment, Till, and Bedrock elevations and thicknesses; more detail on those efforts is provided in Section 3.2. 


\section{Results}

Overall, the elevation of the base of the Sediment layer, the base of the Till, and/or the surface of the Bedrock was calculated using the riverbed, Ro1, and Ro2 depths below the towfish. These same data were also used to generate thicknesses of overlying sediment and till layers when present. All data as described below were provided to LRB as ASCII (.dat) files on October 15, 2018.

\subsection{Bathymetry}

To rectify the stratigraphic data to a known vertical datum, an accurate bathymetric digital elevation model (DEM) was needed for the study area. Accordingly, LRB provided its most recent bathymetric survey for the area (collected August 15-21, 2018), and details, including equipment used and estimates of vertical accuracy, for that survey can be requested from LRB. Matlab was used to generate a bathymetric grid using a nearest neighbor method at $8 \mathrm{ft}$ spacing, required for rectification of the sub-bottom data (Figure 7), in NY State Plane East feet, LWD of $242.4 \mathrm{ft} \mathrm{IGLD} 1985$ at an $8 \mathrm{ft}$ grid spacing.

\subsection{Stratigraphic elevations and thicknesses}

To rectify the stratigraphic surfaces to the required vertical datum, the corrected sub-bottom elevation of the Bedrock below the riverbed, the positive depths below the riverbed of the Bedrock as digitized in SonarWiz were first gridded in Matlab at $5 \mathrm{ft}$ spacings. These elevations were then subtracted from the actual elevation of the riverbed as mapped by the bathymetric survey at the same horizontal positions as the sub-bottom data, generating the elevation of the surface of the Bedrock over the entire study area. This step was repeated for the elevation of the base of the unconsolidated Sediment unit. The elevation of the Till unit was calculated as the difference (if any) of the two surfaces (rectified Sediment and Bedrock and/or riverbed and Bedrock in regions without overlying Sediment). The rectified elevations of the base of the Sediment, the base of the Till, and the top of the Bedrock are provided both as Figure 8 and as associated data files (.dat files). The relative thickness of Sediment, Till, and all material above the bedrock are provided both as Figure 9 and as associated data files (.dat files). 
Figure 7. Bathymetric data provided by LRB at $8 \mathrm{ft}$ grid spacing.

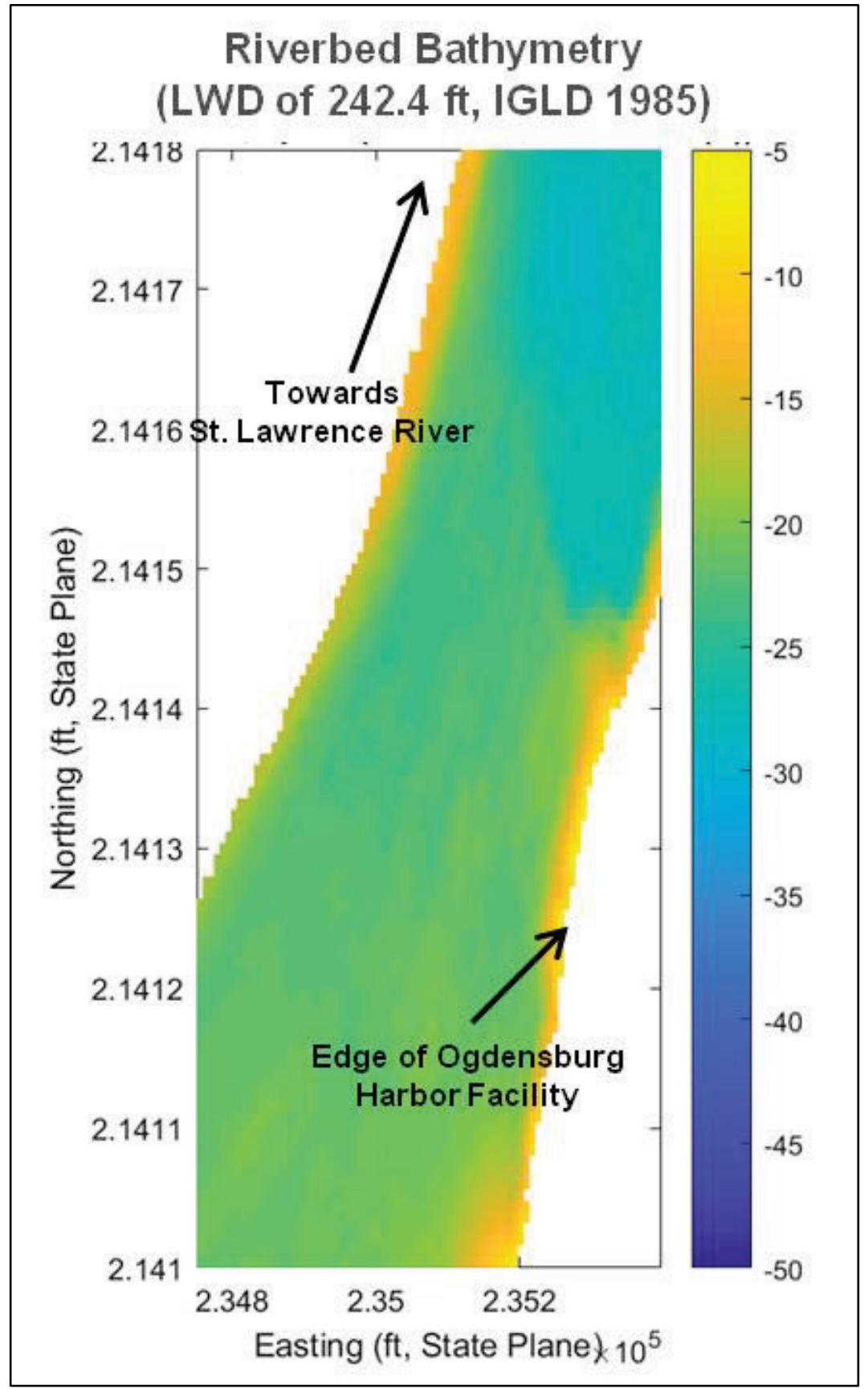


Figure 8. Elevation of the (A): bottom of the Sediment; (B): Bottom of the Till; and (C): top of the Bedrock. All elevations in feet, rectified to the LWD of $242.4 \mathrm{ft}$, IGLD 1985.

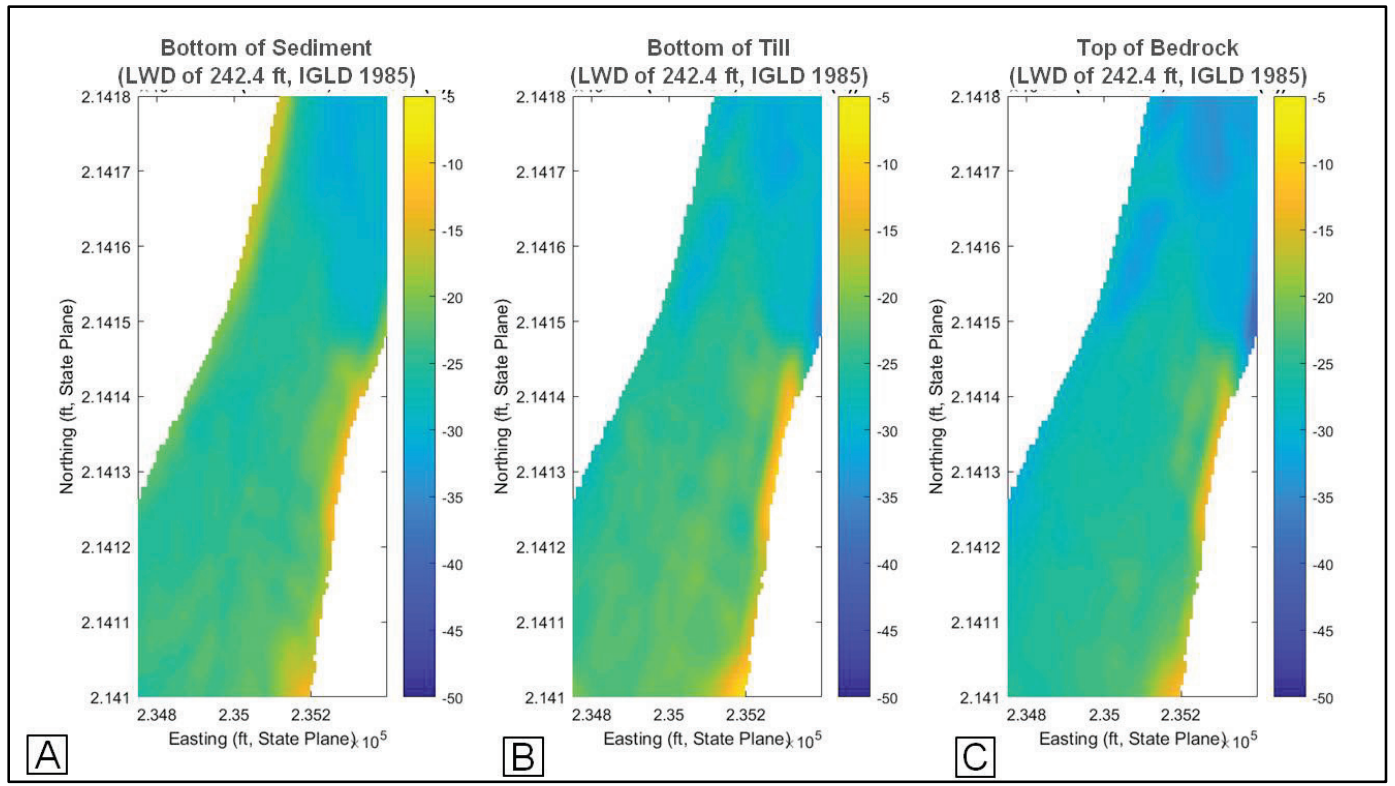

Figure 9. Thickness of stratigraphic units. (A) Sediment thickness in feet below the riverbed; (B) Till thickness in feet below the riverbed; and (C) Total thickness of Sediment and/or Till in feet above the surface of the Bedrock.

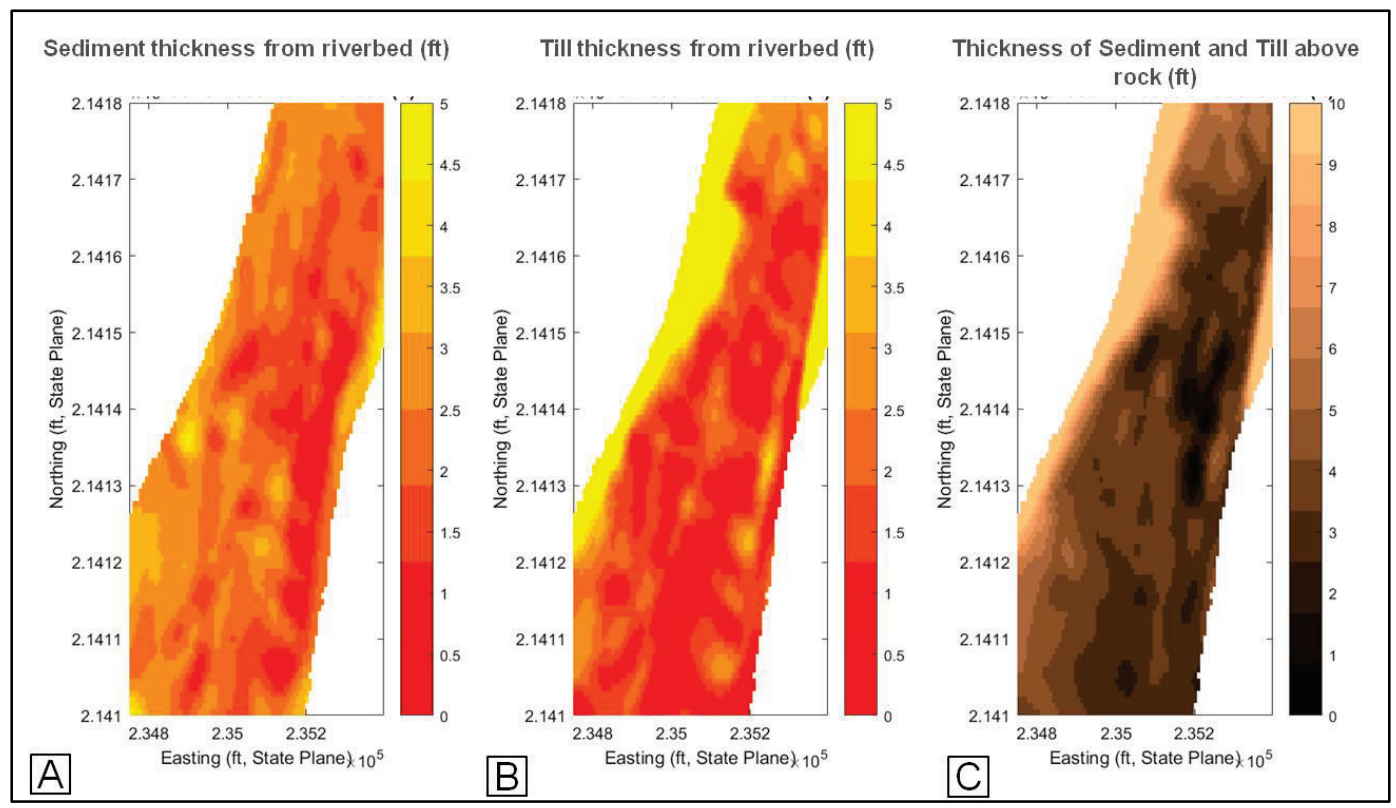

\subsection{Horizontal and vertical error in the sub-bottom data}

The geophysical sub-bottom data are subject to both horizontal and vertical error. With respect to horizontal data, the majority of the error is a function of the error inherent in the system used for navigation; in this case, differential GPS, which has a published horizontal error of $\sim 1 \mathrm{ft}$. 
Since the antenna was mounted directly above the towfish, there is not any significant horizontal layback error in the data.

Vertical error in the thicknesses, and thus elevations, of units derived from the chirp seismic profile is dependent on (1) the assumption of a standard speed of sound in freshwater of $1,485 \mathrm{~m} / \mathrm{s}$, (2) errors in digitization by the processor, and (3) vertical errors in the bathymetric data used to rectify the stratigraphic unit thicknesses to a vertical datum. With respect to speed of sound, the rate at which sound travels through a sedimentary unit is a function primarily of the sediment's density, porosity, and grainsize. Overall, speed of sound in sediment has been determined to be very similar to the speed of sound in water (usually $1 \%-3 \%$ less in sediment than in water (e.g., Hamilton 1965; Gorgas et al. 2002), which translates to a potential vertical error of $<0.3 \mathrm{ft}$. Accordingly, many researchers have suggested that the effect is so minimal for stratigraphic purposes that it can be neglected altogether (e.g., Hamilton 1972; Kibblewhite 1989; Gorgas et al. 2002).

Another source of error is in the digitization process. Chesapeake Technology SonarWiz uses sophisticated algorithms to identify the sediment-water interface and digitize the riverbed. The process is not perfect and requires visual inspection to ensure that the software does not erroneously identify water column noise (such as a school of fish) as the riverbed. Subsequent digitization of underlying reflection surfaces is completed by hand, and slight variations in the position of the mouse will also introduce vertical errors. The error in vertical elevation is directly related to subtle variations in each digitized point as entered by the processor and thus is different for every given project. For this project, the difference in elevation between subsequent horizontal digitized points was determined on multiple regions for 12 seismic lines and averaged $2.01 \mathrm{in}$., with a standard deviation of $0.56 \mathrm{in}$. Note that the errors described above can compound, and lines collected at a lower frequency (such as $0.5-7.2 \mathrm{kHz}$ vs. $2-12 \mathrm{kHz}$ ) had higher errors than lines collected at higher frequencies (vertical error averages of 1.2 in. vs. 2.88 in., respectively). Accordingly, a maximum vertical error for the chirp elevations of 4.4 in. should be used.

In addition to vertical error inherent in the sub-bottom interpretation process, vertical discrepancies between elevations of major stratigraphic contacts in the boreholes vs. an adjacent sub-bottom profile can be caused 
by a variety of factors. The obvious one is distance. Significant spatial variation of the elevation of a given unit, such as Bedrock, was frequently observed within $2 \mathrm{ft}$ along a sub-bottom profile. Accordingly, if a borehole was located more than five linear feet from a sub-bottom profile, elevations were not directly compared. For those boreholes that appear to be located within five linear feet of a sub-bottom line, differences in Bedrock elevation between the two methods can be explained by three main factors, including (1) chirp error (e.g., the difference between borehole and chirp Bedrock elevation was within 4.8 in. [the sub-bottom vertical uncertainty], so the difference might not be significant); (2) spatial variability errors: The differential GPS used to rectify the horizontal position of the chirp data has a horizontal error of up to $1 \mathrm{ft}$. Compounded with a provided potential positioning error of up to $2 \mathrm{ft}$ for each borehole, it is possible that boreholes that seemed to plot within $5 \mathrm{ft}$ of a profile were, in fact, farther away. Accordingly, some of the difference in observed nearby Bedrock elevations could actually due to natural spatial variation; (3) extrapolation errors: On some sub-bottom lines, the surface of the Bedrock was buried below several feet of Till and Sediment, and even the lowest frequency pulses were not able to fully penetrate the upper units, leading to data loss of the Bedrock contact (e.g., Ro1 not digitized). Ro1 was extrapolated in these regions by SonarWiz to produce a complete map, and the extrapolated elevation was compared to the borehole elevation on some lines. A complete list of boreholes and the closest nearby sub-bottom lines, complete with difference in elevations and likely explanation for any differences, is provided in Appendix B.

Despite all of the previously mentioned errors, it is worth noting that the average difference in elevation of Bedrock where comparable to the chirp sub-bottom data averaged only $0.22 \mathrm{ft}$ (standard deviation of $1.40 \mathrm{ft}$ ). Overall, the combination of the two methods yielded a highly reliable map of the complex and variable stratigraphy of Ogdensburg Harbor. 


\section{Discussion}

The spatial variability suggested by the 28 previously collected borehole data was validated and mapped in greater detail via chirp sub-bottom mapping. Although the severe weather conditions precluded the collection of shore parallel oriented sub-bottom lines with $50 \mathrm{ft}$ spacing, the actual data coverage, though unconventional in orientation, ultimately mapped not just the desired study area but also the immediate region (Figure 10). Extending the survey to include the region outside of the dredging area allowed for slightly easier navigation by the vessel captain, and a more comprehensive map of the underlying geology. The largest spatial gap between survey lines in the study area is $58 \mathrm{ft}$, and the elevation of the reflection surfaces mapped on adjacent lines and validated by boreholes was consistent even over those spatial gaps. The average spacing of the individual survey lines was $13 \mathrm{ft}$, resulting in a much denser, if unconventional, data grid than originally planned.

Figure 10. Ogdensburg Harbor. The yellow box represents the planned survey area. The light blue lines show the actual survey tracks.

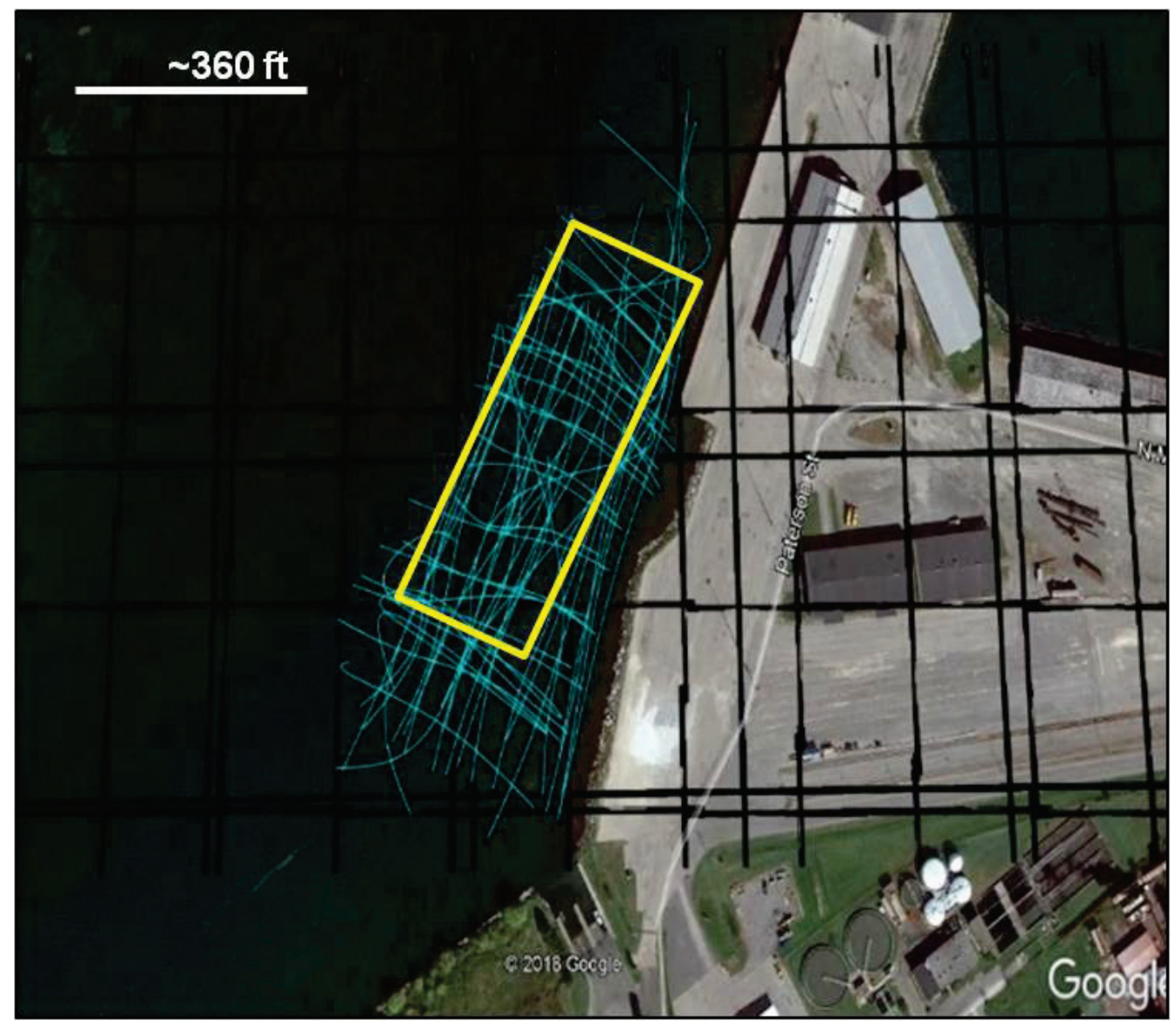


Unconsolidated Sediment was thickest closest to the shoreline and near the entrance to a small boat harbor in the far southwest region of the study area (Figure 9). There was also a wedge of unconsolidated Sediment adjacent to the harbor sidewall on the east side of the study area and, according to borehole logs, is likely comprised of unconsolidated sediment fill. The thickest Till layer ( $\sim 5 \mathrm{ft}$ thick) was observed on the far western edge of the study area, but most of the region is characterized by only a thin veneer of Till $(<2 \mathrm{ft})$. With respect to Bedrock, a small region of it is exposed at the surface near the eastern shoreline but buried on average by $\sim 5 \mathrm{ft}$ of overlying material.

Near the outer part of the study area, closest to the river, elevation data of the various units suggest that at most only a few feet of material (primarily Till to the west and Sediment/Bedrock in the center and east) will need to be removed to reach the new planned depth of -28 feet LWD (Figure 11). More extensive removal of Sediment and Bedrock will be needed with increasing distance towards the shoreline, to include Till as well, particularly along the western edge of the area of concern.

Figure 11. Three-dimensional elevation map of the bathymetry (grey-scale), Sediment (yellow), Till (green) and Bedrock (red) at Ogdensburg Harbor.

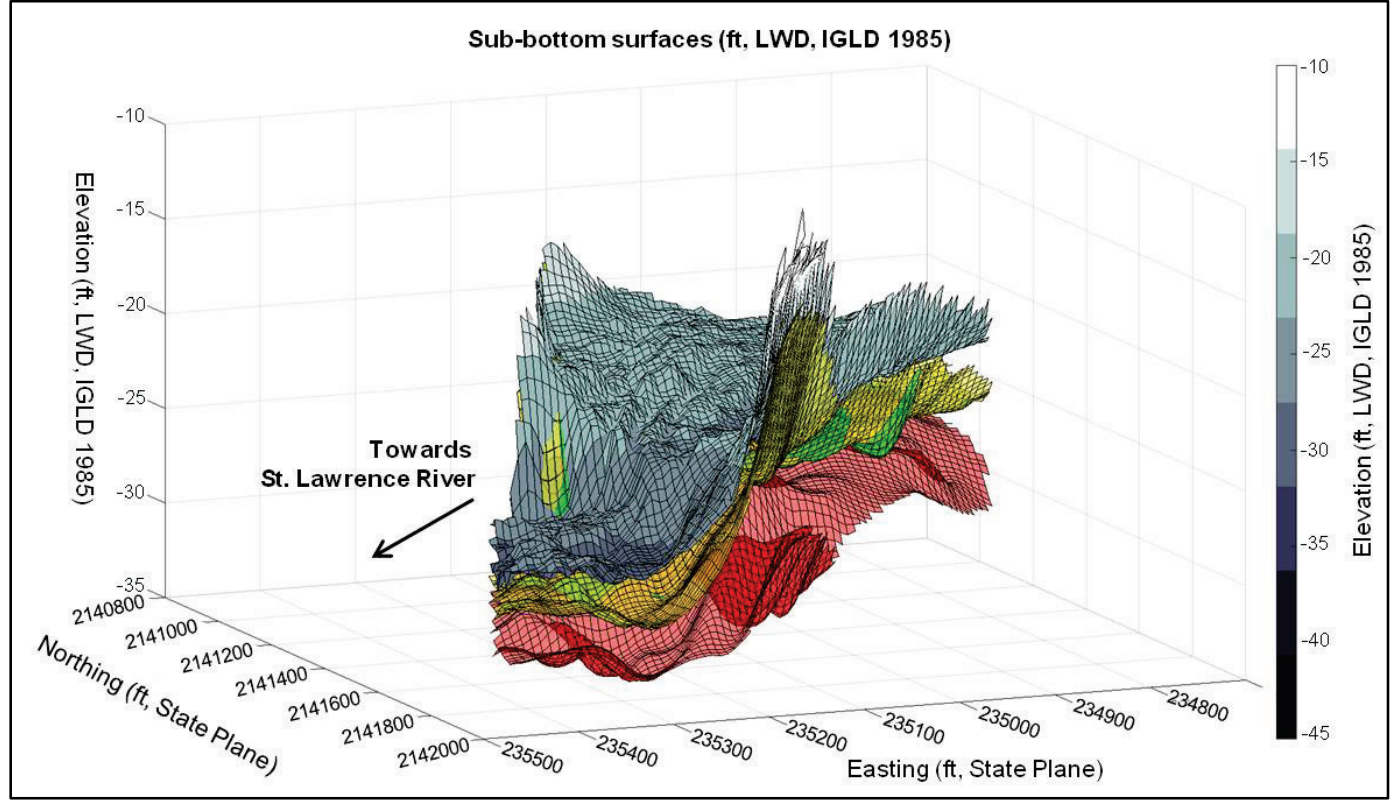




\section{Summary}

An effort is underway to deepen both the channel and a region adjacent to the channel to allow for deeper draft vessels to utilize the harbor. This requires removing material to achieve an operational depth of -28 ft LWD (current operational depth is $-19 \mathrm{ft}$ LWD). Given that dredging unconsolidated Sediment differs greatly from removing Till and Bedrock, an accurate map of the relative elevations and thicknesses of those stratigraphic units is required. Twenty-eight boreholes previously collected in support of this effort indicate that the boundaries between the three main layers are highly variable, and simply drawing a straight-line elevation between, for example, the surface elevation of Bedrock between adjacent cores risks an incorrect estimate of the amount and type of material that need to be removed at any one spot. Accordingly, shallow acoustic, chirp sub-bottom profiles were used to map the spatially variable contacts between unconsolidated Sediment, partially indurated glacial Till, and Bedrock in between the boreholes. This allows for a more accurate map of the highly variable nature of the stratigraphy in this region. 


\section{References}

Carbotte, S. M., R. Bell, W. B. F. Ryan, C. McHugh, A. Slagle, F. O. Nitsche, and J. Rubenstone. 2004. "Environmental Change and Oyster Colonization within the Hudson River Estuary Linked to Holocene Climate.” Geo-Marine Letters 24: 212-224.

Cukur, D., S. Krastel, Y. Tomonaga, M. N. Çağatay, A. F. Meydan, and The PaleoVan Science Team. 2013. "Seismic Evidence of Shallow Gas from Lake Van, Eastern Turkey." Marine and Petroleum Geology 48: 341-353.

Cukur, D., S. Krastel, M. N. Çağatay, E. Damci, A. F. Meydan, and S-P. Kim. 2015. "Evidence of Extensive Carbonate Mounds and Sublacustrine Channels in Shallow Waters of Lake Van, Eastern Turkey, Based on High-Resolution Chirp Sub-Bottom Profiler and Multibeam Echosounder Data." Geo-Marine Letters 35(5): 329-340.

Demarco, L. F. W., A. H. D. F. Klein, and J. A. G. D. Souza. 2017. "Marine Substrate Response from the Analysis of Seismic Attributes in CHIRP Sub-Bottom Profiles." Brazilian Journal of Oceanography 65(3): 332-345.

Félix, C. A., T. S. Martins, C. H. Soares, V. Guesser, L. F. Demarco, B. Suthard, R. C. Barletta, J. A. Souza, and M. M. de Mahiques. 2013. "Some Limitations of Shallow Water Geophysical Devices Imposed by Different Oceanographic and Geological Conditions.” In 2013 IEEE/OES Acoustics in Underwater Geosciences Symposium. IEEE.

Gorgas, T. J., R. H. Wilkens, S. F. Shung, L. N. Frazer, M. D. Richardson, K. B. Briggs, and H. Lee. 2002. "In Situ Acoustic and Laboratory Ultrasonic Sound Speed and Attenuation Measured in Heterogeneous Soft Seabed Sediments: Eel River Shelf, California." Marine Geology 182: 103-119.

Gutowski, M., J. M. Bull, J. K. Dix, T. J. Henstock, P. Hogarth, T. Hiller, T. G. Leighton, and P. R. White. 2008. "3D High-Resolution Acoustic Imaging of the SubSeabed.” Applied Acoustics 69(3): 262-271.

Hamilton, E. L. 1965. "Sound Speed and Related Physical Properties of Sediments from Experimental Mohole (Guadalupe site).” Geophysics 30(2): 257-261.

Hamilton, E. L. 1972. "Compressional Wave Attenuation in Marine Sediments." Geophysics 37: 620-646.

Kibblewhite, A. C. 1989. "Attenuation of Sound in Marine Sediments: A Review with Emphasis on New Low-Frequency Data." Journal of the Acoustical Society of America 86: 716-738.

LeBlanc, L. R., L. Mayer, M. Rufino, S. G. Schock, and J. King. 1992. "Marine Sediment Classification Using the Chirp Sonar." Journal of the Acoustical Society of America 91(1): 107-115. 
Lee, G. H., H. J. Kim, B. Y. Yi, S. M. Nam, B. K. Khim, and M. S. Lim. 2009. “The Acoustic Diversity of the Seabed Based on the Similarity Index Computed from Chirp Seismic Data." ICES Journal of Marine Science 66(2): 227-236.

Morang, A., R. Larson, and L. Gorman. 1997. "Monitoring the Coastal Environment; Part III: Geophysical and Research Methods.” Journal of Coastal Research 13(4): 1064-1085.

Nitsche, F. O., R. Bell, S. M. Carbotte, W. B. F. Ryan, and R. Flood. 2004. "ProcessRelated Classification of Acoustic Data from the Hudson River Estuary.” Marine Geology 209(1-4): 131-145.

Nitsche, F. O., W. B. F. Ryan, S. M. Carbotte, R. E. Bell, A. Slagle, C. Bertinado, R. Flood, T. Kenna, and C. McHugh. 2007. "Regional Patterns and Local Variations of Sediment Distribution in the Hudson River Estuary." Estuarine, Coastal, and Shelf Science 71: 259-277.

Plets, R. M. K., J. K. Dix, J. R. Adams, J. M. Bull, T. J. Henstock, M. Gutowski, and A. I. Best. 2009. "The Use of a High-Resolution 3D Chirp Sub-Bottom Profiler for the Reconstruction of the Grace Dieu, (1439), River Hamble, UK.” Journal of Archaeological Science 36: 408-418.

Roberts, H. H., and J. Supan. 2000. "Acoustic Surveying of Ultra-Shallow Water Bottoms $(<2.0 \mathrm{~m})$ for Both Engineering and Environmental Applications." Offshore Technology Conference, 1-4 May 2000, Houston, TX.

Schock, S. G. 2004. "A Method for Estimating the Physical and Acoustic Properties of the Sea Bed Using Chirp Sonar Data.” IEEE Journal of Oceanographic Engineering 29(4): 1200-1217.

Schock, S. G., and L. R. LeBlanc. 1990. "Some Applications of the Chirp Sonar." Oceans 90: 24-26.

Schwamborn, G. K., J. K. Dix, J. M. Bull, and V. Rachold. 2002. "High-Resolution Seismic and Ground Penetrating Radar-Geophysical Profiling of a Themokarst Lake in the Western Lena Delta, Northern Siberia." Permafrost and Periglacial Studies 13: 259-269.

Wadman, H. M., and J. E. McNinch. 2020. Application of Chirp Acoustic Sub-Bottom Data in Riverine Environments: Identification of Underlying Rocky Hazards at Cape Girardeau, Missouri, and Thebes, Illinois. MRG\&P Report 31. Vicksburg, MS: US Army Engineer Research and Development Center. 


\section{Appendix A: Chirp Sub-Bottom Files}

Table 1 lists all chirp sub-bottom files collected in support of this project. Date of collection, sonar frequency settings, and total data record imported are noted for each line. Sub-bottom lines collected but ultimately not used in the data interpretation are highlighted.

Table 1. All chirp sub-bottom files collected in support of this project.

\begin{tabular}{|c|c|c|c|c|}
\hline Line Name & Date Collected & Pulse & $\begin{array}{l}\text { Record/Trigger } \\
\text { /Power }\end{array}$ & Reflectors \\
\hline OHSP_01 & 27-Aug-18 & $0.5-7.2 \mathrm{kHz}$ & $100 / 100100 \%$ & R01, R02 \\
\hline OHSP_02 & 27-Aug-18 & $0.5-7.2 \mathrm{kHz}$ & $100 / 100100 \%$ & R01, R02 \\
\hline OHSP_03 & 27-Aug-18 & $0.5-7.2 \mathrm{kHz}$ & $100 / 100100 \%$ & R01, R02 \\
\hline OHSP_04 & 27-Aug-18 & $0.5-7.2 \mathrm{kHz}$ & $100 / 100100 \%$ & R01, R02 \\
\hline OHSP_05 & 27-Aug-18 & $0.5-7.2 \mathrm{kHz}$ & $100 / 100100 \%$ & R01, R02 \\
\hline OHSP_06 & 27-Aug-18 & $0.5-7.2 \mathrm{kHz}$ & $100 / 100100 \%$ & R01, R02 \\
\hline OHSP_07 & 27-Aug-18 & $0.5-7.2 \mathrm{kHz}$ & $100 / 100100 \%$ & R02 \\
\hline OHSP_08 & 27-Aug-18 & $0.5-7.2 \mathrm{kHz}$ & $100 / 100100 \%$ & R01, R02 \\
\hline OHSP_09 & 27-Aug-18 & $0.5-7.2 \mathrm{kHz}$ & $100 / 100100 \%$ & R01, R02 \\
\hline OHSP_10 & 27-Aug-18 & $0.5-7.2 \mathrm{kHz}$ & $100 / 100100 \%$ & R01, R02 \\
\hline OHSP_11 & 27-Aug-18 & $0.5-7.2 \mathrm{kHz}$ & $100 / 100100 \%$ & R01, R02 \\
\hline OHSP_12 & 27-Aug-18 & $0.5-7.2 \mathrm{kHz}$ & $100 / 100100 \%$ & R01, R02 \\
\hline OHSP_13 & 27-Aug-18 & $0.5-7.2 \mathrm{kHz}$ & $100 / 100100 \%$ & R01, R02 \\
\hline OHSP_14 & 27-Aug-18 & $0.5-7.2 \mathrm{kHz}$ & $100 / 100100 \%$ & R01, R02 \\
\hline OHSP_15 & 27-Aug-18 & $0.5-7.2 \mathrm{kHz}$ & $100 / 100100 \%$ & R01, R02 \\
\hline OHSP_16 & 27-Aug-18 & $0.5-7.2 \mathrm{kHz}$ & $100 / 100100 \%$ & R01, R02 \\
\hline OHSP_17 & 27-Aug-18 & $0.5-7.2 \mathrm{kHz}$ & $100 / 100100 \%$ & R01, R02 \\
\hline OHSP_18 & 27-Aug-18 & $0.5-7.2 \mathrm{kHz}$ & $100 / 100100 \%$ & R01, R02 \\
\hline OHSP_19 & 27-Aug-18 & $0.5-7.2 \mathrm{kHz}$ & $100 / 100100 \%$ & R01, R02 \\
\hline OHSP_20 & 27-Aug-18 & $0.5-7.2 \mathrm{kHz}$ & $100 / 100100 \%$ & R01, R02 \\
\hline OHSP_21 & 27-Aug-18 & $0.5-7.2 \mathrm{kHz}$ & $100 / 100100 \%$ & R01, R02 \\
\hline OHSP_22 & 27-Aug-18 & $0.5-7.2 \mathrm{kHz}$ & $100 / 100100 \%$ & R01, R02 \\
\hline OHSP_23 & 27-Aug-18 & $2-12 \mathrm{kHz}$ & $50 / 50100 \%$ & none - bad line \\
\hline OHSP_24 & 27-Aug-18 & $2-12 \mathrm{kHz}$ & $50 / 50100 \%$ & R01, R02 \\
\hline OHSP_25 & 28-Aug-18 & $0.5-7.2 \mathrm{kHz}$ & $100 / 100100 \%$ & R01, R02 \\
\hline
\end{tabular}




\begin{tabular}{|c|c|c|c|c|}
\hline Line Name & Date Collected & Pulse & $\begin{array}{l}\text { Record/Trigger } \\
\text { /Power }\end{array}$ & Reflectors \\
\hline OHSP_26 & 28-Aug-18 & $0.5-7.2 \mathrm{kHz}$ & $100 / 100100 \%$ & R01, R02 \\
\hline OHPAR_01 & 28-Aug-18 & 2-12 kHz & $50 / 50100 \%$ & R01, R02 \\
\hline OHPAR_02 & 28-Aug-18 & 2-12 kHz & $50 / 50100 \%$ & R01, R02 \\
\hline OHPAR_03 & 28-Aug-18 & 2-12 kHz & $50 / 50100 \%$ & R01, R02 \\
\hline OHPAR_04 & 28-Aug-18 & 2-12 kHz & $50 / 50100 \%$ & R01, R02 \\
\hline OHPAR_05 & 28-Aug-18 & 2-12 kHz & $50 / 50100 \%$ & R01, R02 \\
\hline OHPAR_06 & 28-Aug-18 & 2-12 kHz & $50 / 50100 \%$ & R01, R02 \\
\hline OHPAR_07 & 28-Aug-18 & 2-12 kHz & $50 / 50100 \%$ & R01, R02 \\
\hline OHPAR_08 & 28-Aug-18 & 2-12 kHz & $50 / 50100 \%$ & R01, R02 \\
\hline OHPAR_08b & 28-Aug-18 & $2-12 \mathrm{kHz}$ & $50 / 50100 \%$ & R01, R02 \\
\hline OHPAR_09 & 28-Aug-18 & $2-12 \mathrm{kHz}$ & $50 / 50100 \%$ & R01, some R02 \\
\hline OHPAR_10 & 28-Aug-18 & 2-12 kHz & $50 / 50100 \%$ & R01, some R02 \\
\hline OHPAR_11 & 28-Aug-18 & $0.5-6 \mathrm{kHz}$ & $50 / 50100 \%$ & none - bad line \\
\hline OHPAR_12 & 28-Aug-18 & $0.5-7.2 \mathrm{kHz}$ & $50 / 50100 \%$ & none - bad line \\
\hline OHPAR_13 & 28-Aug-18 & $0.5-7.2 \mathrm{kHz}$ & $50 / 50100 \%$ & R01 \\
\hline OHPAR_14 & 28-Aug-18 & $0.5-7.2 \mathrm{kHz}$ & $50 / 50100 \%$ & R01, R02 \\
\hline OHPAR_15 & 28-Aug-18 & $0.5-7.2 \mathrm{kHz}$ & $50 / 50100 \%$ & R01, R02 \\
\hline OHPAR_16 & 28-Aug-18 & $0.5-7.2 \mathrm{kHz}$ & $50 / 50100 \%$ & R01, R02 \\
\hline OHPAR_17 & 28-Aug-18 & $0.5-7.2 \mathrm{kHz}$ & $50 / 50100 \%$ & R01, R02 \\
\hline OHPAR_18 & 28-Aug-18 & $0.5-7.2 \mathrm{kHz}$ & $100 / 100100 \%$ & R01, R02 \\
\hline OHPAR_19 & 28-Aug-18 & $0.5-7.2 \mathrm{kHz}$ & $100 / 100100 \%$ & R01, R02 \\
\hline OHPAR_20 & 28-Aug-18 & $0.5-7.2 \mathrm{kHz}$ & $100 / 100100 \%$ & R01, R02 \\
\hline OHPAR_2Ob & 28-Aug-18 & $0.5-7.2 \mathrm{kHz}$ & $100 / 100100 \%$ & R01, R02 \\
\hline OHZZ_01 & 28-Aug-18 & 2-12 kHz & $100 / 100100 \%$ & R01, R02 \\
\hline OHZZ_02 & 28-Aug-18 & $2-12 \mathrm{kHz}$ & $100 / 100100 \%$ & R01, R02 \\
\hline OHZZ_03 & 28-Aug-18 & 2-12 kHz & $200 / 200100 \%$ & none - bad line \\
\hline OHZZ_04 & 28-Aug-18 & $0.5-4.5 \mathrm{kHz}$ & $200 / 200100 \%$ & R01, R02 \\
\hline
\end{tabular}




\section{Appendix B: Borehole and Chirp Comparisons}

Table 2 lists the borehole IDs and locations, as well as the name and distance to the closest sub-bottom profile. Where possible, the differences in elevation of the rock surface (Bedrock) as observed in the boreholes vs. the nearest sub-bottom profile are provided as well. The elevation of top of Bedrock as observed in boreholes located farther than five linear feet from a chirp sub-bottom profile were not directly compared to a given subbottom elevation. Potential causes of the vertical discrepancies are explained in detail in the preceding Section 3.3.

Table 2. The borehole IDs and locations, the name and distance to the closest sub-bottom profile, and differences in Bedrock elevation between the boreholes and the adjacent subbottom profiles.

\begin{tabular}{|c|c|c|c|c|c|c|}
\hline $\begin{array}{l}\text { Borehole } \\
\text { ID }\end{array}$ & $\begin{array}{l}\text { Seismic } \\
\text { Line(s) }\end{array}$ & $\begin{array}{l}\text { Distance } \\
\text { from } \\
\text { Sub-bottom } \\
\text { Line }\end{array}$ & $\begin{array}{l}\text { Boring: Top of } \\
\text { Bedrock +/- } \\
\text { LWD (ft) }\end{array}$ & $\begin{array}{l}\text { Chirp: Top of } \\
\text { Bedrock +/- } \\
\text { LWD (ft) }\end{array}$ & $\begin{array}{l}\text { Bedrock } \\
\text { Difference } \\
\text { Boring/Chirp (ft) }\end{array}$ & Explanation \\
\hline CLEWB1 & OHPAR_08b & $4 \mathrm{ft}$ & -25 & -23.5 & -1.5 & Spatial Variability \\
\hline CLEWB10 & OHPAR_11 & $20 \mathrm{ft}$ & -26.1 & $\mathrm{n} / \mathrm{a}$ & $\mathrm{n} / \mathrm{a}$ & $n / a$ \\
\hline CLEWB11 & OHPAR_08b & $3 \mathrm{ft}$ & -26.7 & -28.5 & 1.8 & Spatial Variability \\
\hline CLEWB2 & OHSP_24 & $6 \mathrm{ft}$ & -22.6 & $\mathrm{n} / \mathrm{a}$ & $\mathrm{n} / \mathrm{a}$ & $n / a$ \\
\hline CLEWB3 & OHZZ_01 & $5 \mathrm{ft}$ & -25.8 & -24 & -1.8 & Spatial Variability \\
\hline CLEWB4 & OHSP22 & $4 \mathrm{ft}$ & -21.8 & -23 & 1.2 & Spatial Variability \\
\hline CLEWB5 & OHZZ_01 & $5 \mathrm{ft}$ & -23.9 & -24 & 0.1 & W/in chirp error \\
\hline CLEWB6 & OHPAR_10 & $2 \mathrm{ft}$ & -22 & -23.9 & 1.9 & Spatial Variability \\
\hline CLEWB7 & OHPAR_08b & $20 \mathrm{ft}$ & -27.1 & -25 & -2.1 & Spatial Variability \\
\hline CLEWB8 & OHPAR_11 & $9 \mathrm{ft}$ & -24.6 & -23.3 & -1.3 & Spatial Variability \\
\hline CLEWB9 & OHZZ_O2 & $8 \mathrm{ft}$ & -25.6 & -23.7 & -1.9 & Spatial Variability \\
\hline CLEWB-12 & OHPAR_11 & $3 \mathrm{ft}$ & -25.7 & -25.5 & -0.2 & W/in chirp error \\
\hline DC13-02 & OHSP_18 & $12 \mathrm{ft}$ & -26.1 & $\mathrm{n} / \mathrm{a}$ & $\mathrm{n} / \mathrm{a}$ & $n / a$ \\
\hline DC13-03 & OHSP_09 & $15 \mathrm{ft}$ & $\mathrm{n} / \mathrm{a}$ & $n / a$ & $\mathrm{n} / \mathrm{a}$ & $\mathrm{n} / \mathrm{a}$ \\
\hline DC13-04 & OHSP_25 & $24 \mathrm{ft}$ & $n / a$ & $\mathrm{n} / \mathrm{a}$ & $\mathrm{n} / \mathrm{a}$ & $n / a$ \\
\hline DC13-01 & OHPAR_04 & $7 \mathrm{ft}$ & -26.2 & -24.8 & -1.4 & Spatial Variability \\
\hline DC13-05 & OHSP_19 & $2 \mathrm{ft}$ & -24.2 & -24.6 & 0.4 & W/in chirp error \\
\hline DC13-06 & OHZZ_02 & $4 \mathrm{ft}$ & -28.6 & -27 & -1.6 & Spatial Variability \\
\hline DC13-07 & OHPAR_11 & $48 \mathrm{ft}$ & $n / a$ & $\mathrm{n} / \mathrm{a}$ & $\mathrm{n} / \mathrm{a}$ & $n / a$ \\
\hline DC17-5 & OHPAR_02 & $3 \mathrm{ft}$ & -26.2 & -26.5 & 0.3 & W/in chirp error \\
\hline
\end{tabular}




\begin{tabular}{|l|l|l|l|l|l|l|}
\hline $\begin{array}{l}\text { Borehole } \\
\text { ID }\end{array}$ & $\begin{array}{l}\text { Seismic } \\
\text { Line(s) }\end{array}$ & $\begin{array}{l}\text { Distance } \\
\text { from } \\
\text { Sub-bottom } \\
\text { Line }\end{array}$ & $\begin{array}{l}\text { Boring: Top of } \\
\text { Bedrock +/- } \\
\text { LWD (ft) }\end{array}$ & $\begin{array}{l}\text { Chirp: Top of } \\
\text { Bedrock +/- } \\
\text { LWD (ft) }\end{array}$ & $\begin{array}{l}\text { Bedrock } \\
\text { Difference } \\
\text { Boring/Chirp (ft) }\end{array}$ & Explanation \\
\hline DC17-6 & OHPAR_19 & $6 \mathrm{ft}$ & -25.8 & -25 & -0.8 & Extrapolation \\
\hline DC17-9 & OHZZ_01 & $2 \mathrm{ft}$ & -23.6 & -25.4 & 1.8 & Extrapolation \\
\hline DC17-12 & OHPAR_14 & $6 \mathrm{ft}$ & -25.7 & -25.5 & -0.2 & W/in chirp error \\
\hline DC17-13 & OHPAR_07 & $10 \mathrm{ft}$ & $\mathrm{n} / \mathrm{a}$ & $\mathrm{n} / \mathrm{a}$ & $\mathrm{n} / \mathrm{a}$ & n/a \\
\hline FCA-1 & OHPAR_17 & $4 \mathrm{ft}$ & -26.1 & -26.6 & 0.5 & Spatial Variability \\
\hline FCA-2 & OHSP_16 & $1 \mathrm{ft}$ & -27.9 & -27.3 & -0.6 & Spatial Variability \\
\hline FCA-3 & OHPAR_16 & $2 \mathrm{ft}$ & -33.2 & -31.7 & -1.5 & $\begin{array}{l}\text { No Bedrock in } \\
\text { Borehole }\end{array}$ \\
\hline FCA-4 & OHPAR_16 & $4 \mathrm{ft}$ & -29.8 & -32.1 & 2.3 & $\begin{array}{l}\text { No Bedrock in } \\
\text { Borehole }\end{array}$ \\
\hline
\end{tabular}




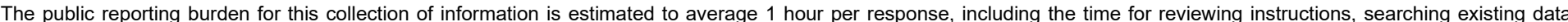

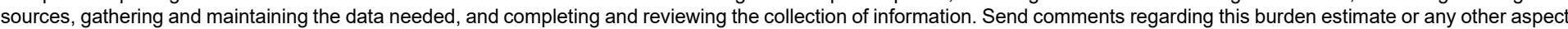

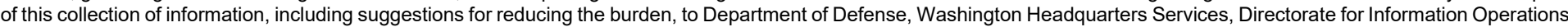

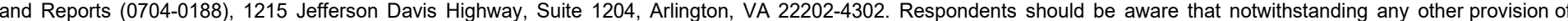
law, no person shall be subject to any penalty for failing to comply with a collection of information if it does not display a currently valid OMB control number. PLEASE DO NOT RETURN YOUR FORM TO THE ABOVE ADDRESS.

\begin{tabular}{l|l|l}
$\begin{array}{l}\text { 1. REPORT DATE } \\
\text { May } 2021\end{array}$ & $\begin{array}{l}\text { 2. REPORT TYPE } \\
\text { Final Report }\end{array}$ & 3. DATES COVERED (FrOm - To)
\end{tabular}

\section{TITLE AND SUBTITLE}

Elevation of Underlying Basement Rock, Ogdensburg Harbor, NY 5a. CONTRACT NUMBER

5b. GRANT NUMBER

5c. PROGRAM ELEMENT NUMBER

5d. PROJECT NUMBER

5e. TASK NUMBER

5f. WORK UNIT NUMBER

8. PERFORMING ORGANIZATION REPORT NUMBER

ERDC/CHL TR-21-8

10. SPONSOR/MONITOR'S ACRONYM(S) USACE LRB

11. SPONSOR/MONITOR'S REPORT NUMBER(S)

\section{DISTRIBUTION/AVAILABILITY STATEMENT}

Approved for public release; distribution is unlimited.

\section{SUPPLEMENTARY NOTES}

Funding Account Code U4361444, AMSCO Code 086000, MIPR Number CCLC 35DB74

\section{ABSTRACT}

Over six linear miles of shallow acoustic reflection geophysical data were collected in an $800 \mathrm{ft}$ by $300 \mathrm{ft}$ survey region at Ogdensburg Harbor, Ogdensburg, NY. To better accommodate modern commercial vessels and expand the harbor's capacity, the current navigable depth of $-19 \mathrm{ft}$ Low Water Depth (LWD) needs to be increased to $-28 \mathrm{ft}$ LWD, and an accurate map of the nature of the riverbed material (e.g., unconsolidated sediment, partially indurated glacial till, or bedrock) is required to effectively plan for removal. A total of 28 boreholes were previously collected to map the stratigraphy, and the effort revealed significant spatial variability in unit thickness and elevation between adjacent boreholes. To accurately map this variable stratigraphy, chirp sub-bottom profiles were collected throughout the region, with an average line spacing of $13 \mathrm{ft}$. These sub-bottom data, validated and augmented by the borehole data, resulted in highresolution spatial maps of stratigraphic elevation and thickness for the study area. The data will allow for more accurate assessment of the type and extent of different dredging efforts required to achieve a future uniform depth of $-28 \mathrm{ft}$ LWD for the navigable region.

\section{SUBJECT TERMS}

Borings, Dredging, Geomorphology, Geophysical surveys, Ogdensburg (N.Y.)—Harbors, Sedimentation and deposition

\section{SECURITY CLASSIFICATION OF:}

\begin{tabular}{|l|c|l|}
\hline a. REPORT & b. ABSTRACT & c. THIS PAGE \\
Unclassified & Unclassified & Unclassified \\
\hline
\end{tabular}

17. LIMITATION OF ABSTRACT

SAR
18. NUMBER 19a. NAME OF RESPONSIBLE PERSON

PAGES

36
Heidi M. Wadman

19b. TELEPHONE NUMBER (Include area code)

(252) 261-6840 